\title{
Comparing the Deep Root Growth and Water Uptake of Intermediate Wheatgrass (Kernza®) to Alfalfa.
}

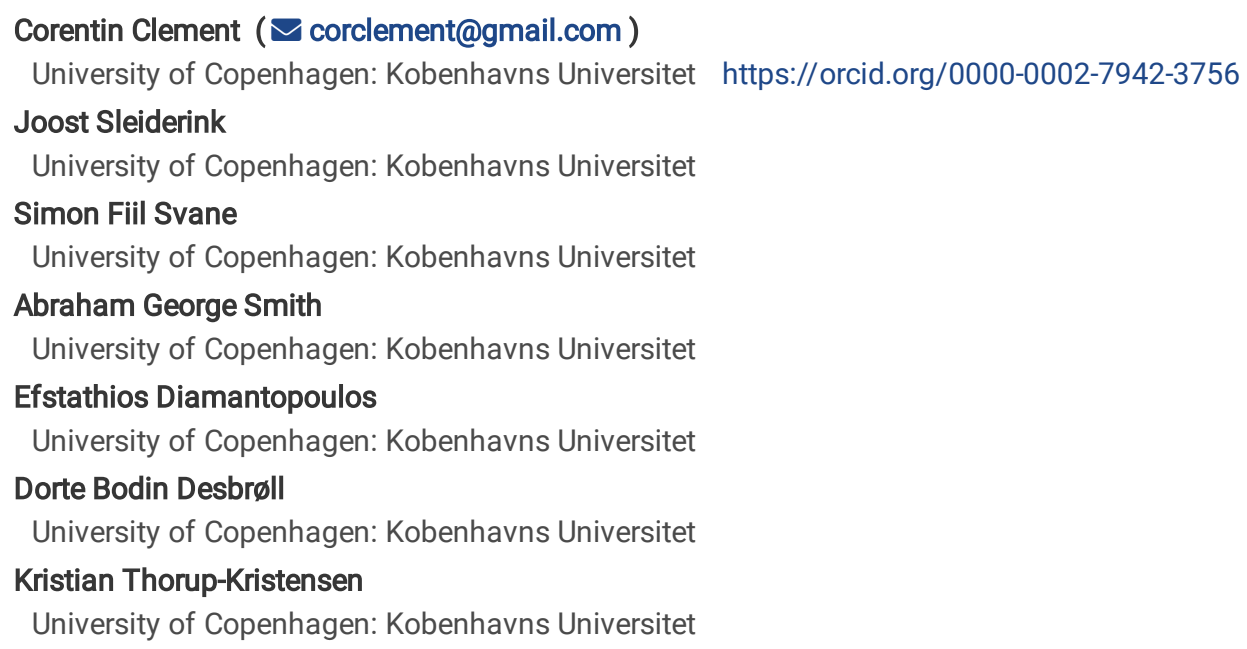

\section{Research Article}

Keywords: Deep roots, Water Uptake, Perennial crop, Intermediate wheatgrass, Kernza, Alfalfa

Posted Date: October 5th, 2021

DOI: https://doi.org/10.21203/rs.3.rs-946234/v1

License: (c) (i) This work is licensed under a Creative Commons Attribution 4.0 International License. Read Full License

Version of Record: A version of this preprint was published at Plant and Soil on January 19th, 2022. See the published version at https://doi.org/10.1007/s11104-021-05248-6. 


\section{Abstract}

Aims

Water is the most important yield-limiting factor worldwide and drought is predicted to increase in the future. Perennial crops with more extensive and deep root systems could access deep stored water and build resilience to water shortage. In the context of human nutrition, perennial grain crops are very interesting. However, it is still questionable whether they are effective in using subsoil water. We compared intermediate wheatgrass $\left(\right.$ Kernza $\left.^{\circledR}\right)$ Thinopyrum intermedium, a perennial grain crop, to alfalfa Medicago sativa, a perennial forage, for subsoil root growth and water uptake.

Methods

Using TDR sensors, deuterium tracer labelling, minirhizotrons and the Hydrus-1D model we characterised the root distribution and water uptake patterns of these two perennial crops during two cropping seasons under field conditions down to $2.5 \mathrm{~m}$ soil depth.

Results

Both crops grew roots down to $2.0 \mathrm{~m}$ depth that were active in water uptake but alfalfa was deeper rooted than intermediate wheatgrass. All experimental methods concluded that alfalfa used more water from below $1.0 \mathrm{~m}$ depth than intermediate wheatgrass. However, simulations predicted that intermediate wheatgrass used more than $20 \mathrm{~mm}$ of water after anthesis from below $1 \mathrm{~m}$ soil depth. Simulations confirmed the advantage of deep roots in accessing deep soil water under drought.

Conclusions

In regions with high groundwater recharge, growing deep-rooted perennial crops have great potential to exploit deep soil water that is often left unused. However, the road to a profitable perennial grain crop is still long and breeding intermediate wheatgrass (Kernza ${ }^{\circledR}$ ) cultivars for increased root growth at depth seems to be a worthy investment for the development of more drought tolerant cultivars.

\section{Introduction}

Water is the most yield-limiting factor globally and water scarcity will increasingly constrain food production in the future due to climate change and increased human water consumption (Rosegrant et al. 2009; Kummu et al. 2016). In Europe, increased evapotranspiration and a decrease in rainfall events in summer are expected to cause major water limitations, affecting both rainfed-and irrigated-agricultural systems (Turral et al. 2011; Dezsi et al. 2018; Rasmussen et al. 2018; Toreti et al. 2019). Moreover, sustainable intensification of agricultural systems is becoming a priority to meet increasing food demand and limit their associated environmental costs (Hunter et al. 2017; Fischer and Connor 2018). Part of this challenge is to find adaptation strategies that will increase the efficiency and resilience of agricultural systems regarding water usage.

In this quest, exploitation of deep soil resources has been neglected despite the advantages that increased rooting depth confers to plants and agricultural systems (Lynch and Wojciechowski 2015; Thorup-Kristensen et al. 2020). In particular, deep subsoil water acquisition has led to substantial yield increase under drought in crops such as wheat (Manschadi et al. 2006; Kirkegaard et al. 2007; Cutforth et al. 2009), rice (Fukai and Cooper 1995) maize (Kondo et al. 2000) sorghum and sunflower (Bremner and Fazekas de St. Groth 1986). Deep rooting, defined by roots growing below $1 \mathrm{~m}$ soil depth (Maeght et al. 2013), is considered to be a key trait for drought avoidance (Hund et al. 2009; Lynch 2013). However, the sole presence of deep roots is not automatically an advantageous trait. First, the presence of roots in moist subsoil have been shown to be a poor indicator of their activity, especially under water stress (Prechsl et al. 2015; Rasmussen et al. 2019). Second, as deep rooting is generally associated with more extensive water exploitation, in water-limited environments, a more conservative water use could be advantageous to saving water during earlier stages for later use (Richards and Passioura 1989; Schoppach et al. 2013). Nonetheless, in environments where water has been historically in excess and available in the subsoil, such as northern Europe, growing deeper-rooted crops can increase resilience to future climate fluctuations to sustain agricultural production. Benefits from deeper rooted crops must be considered in the context of the farming systems and management practices (Lilley and Kirkegaard 2016; Thorup-Kristensen and Kirkegaard 2016).

Along the soil-plant-atmosphere continuum, water moves passively from areas of high water potential (i.e. the soil) to areas of low water potential (i.e. the atmosphere) along a water potential gradient set up by transpiration (for a review see McElrone et al. (2013)). Due to the complexity of the hydraulic resistances to water flow that occur along the soil-plant system and their spatial and temporal variability it is difficult to make assumptions on root water uptake, see reviews by Lobet et al. (2014) and Ahmed et al. (2018). First, the movement of water in the soil, within the rhizosphere and the plants is governed by non-linear functions that vary according to the plant and environmental conditions. Second, plants develop physiological responses to soil drying and increase in vapor pressure deficit, which are highly variable in time and control the plant water uptake such as transpiration regulation (Vadez et al. 2014), mucilage exudation (Ahmed et al. 2014), compensated root growth (Vandoorne et al. 2012) or soil structure exploitation (e.g. clumping of roots in macropores (White and Kirkegaard 2010)). 
Understanding root growth and functioning under field conditions is particularly challenging due to the complex soil-plant-atmosphere interactions and even more challenging with increasing soil depth (Maeght et al. 2013). Research on deep roots is not common, especially due to the time, labor and costs involved (Thorup-Kristensen et al. 2020) but recent advances in sensor technology, stable isotope techniques and imaging devices offer exciting perspectives. In addition coupling empirical measurements with predictive models offers an interesting avenue for understanding the processes involved at great soil depth (Lilley and Kirkegaard 2011; Mazzacavallo and Kulmatiski 2015; Zheng et al. 2018) and will likely overcome methodological restrictions and biases such as destructive sampling, difficulty in obtaining in-situ and repeated chronological measurements.

Due to their extensive root systems, year-round ground cover and lower input requirements, perennial crops are drawing increasing attention (Cox et al. 2006; Crews and Dehaan 2015). From these characteristics, perennial cropping systems tend to provide ecosystem benefits such as higher soil carbon sequestration, reduced nutrient leaching and increased subsoil water uptake (Mclsaac et al. 2010; Culman et al. 2013) compared to annual cropping systems (Pimentel et al. 2012; Crews et al. 2016). However, most of the perceived benefits of perennial farming systems derive from studies on forage and native grassland as discussed by Culman et al. (2013). With $80 \%$ of the human diet being cereals and oil seed crops, the development of perennial grain crops is attracting international interest (Cox et al. 2006; FAO 2013; Crews and Dehaan 2015). Among perennial grain crops that offer worthy prospects for adoption, intermediate wheatgrass (Kernza ${ }^{\circledR}$ ), Thinopyrum intermedium, has been attracting researchers and farmers attention (FAO 2013; Wayman et al. 2019). It has long been used as a forage crop but also produces edible seeds (Dehaan et al. 2018). While there are indications that intermediate wheatgrass is deep rooted (Cox et al. 2006), little is known about the extent of its rooting system and root activity below $1.5 \mathrm{~m}$ depth. Furthermore, intercropping intermediate wheatgrass with a perennial legume maintains yields while reducing the need for nitrogen fertilization (Tautges et al. 2018). Alfalfa, Medicago sativa, is a common perennial legume cultivated as a forage crop and used in crop rotations to enhance soil structure and rebuild nitrogen content (Angers and Caron 1998). Due to its extensive root growth, alfalfa is known for its deep water use (Angus et al. 2001; McCallum et al. 2001; Ward et al. 2002).

Therefore, this study focuses on two research questions: (1) how does root distribution of intermediate wheatgrass vary with soil depth? and (2) how effective are roots of intermediate wheatgrass in using deep soil water? Performances of intermediate wheatgrass were compared to alfalfa due to its deep root system, well-known capacity of using deep soil water and agronomical interest as a companion crop. Field investigation combined soil moisture content sensors, deuterium tracer labelling and minirhizotron imaging to characterize root distribution and water uptake patterns down to $2.5 \mathrm{~m}$ soil depth. Quantitative estimation of the contribution of deep soil layers to crop transpiration was done using the Hydrus1D model.

\section{Materials And Methods}

\section{Site description and meteorological data}

The experiment was conducted at the experimental farm of the University of Copenhagen $\left(55.66815^{\circ} \mathrm{N}, 12.30848^{\circ} \mathrm{E}\right)$. Climate at the study site was a marine west coast climate (Cfb according to the Köppen climate classification) and local weather conditions were obtained by an on-site weather station (Svane et al. 2020). With $100 \mathrm{~mm}$ less rainfall and $67 \mathrm{~mm}$ higher reference evapotranspiration during the growing season, $2018 \mathrm{was}$ a drier year than 2019 (Fig. 1). In May, June and July 2018 rainfall was consistently lower than the 56-year $3^{\text {rd }}$ quartile, making 2018 a very dry year. The soil, a haplic Luvisol according to the FAO soil classification system (FAO 2006), changes from a sandy loam with approximately $15 \%$ of clay in the topsoil to a loam below $0.25 \mathrm{~m}$ with approximately $20 \%$ of clay (Table 1 ). The subsoil was characterised by the presence of calcareous till, generally found below $1 \mathrm{~m}$ soil depth (Nielsen et al. 2010). Soil bulk density was $1.4 \mathrm{~g} / \mathrm{cm}^{3}$ in the topsoil and increased to $1.8 \mathrm{~g} / \mathrm{cm}^{3}$ in the subsoil. At $0.75,1.5$ and $2.5 \mathrm{~m}$ soil depth, water retention was measured using the standard sand box and pressure plate method (Table 1; Supplemental Fig. 1).

\section{Plant material, establishment and management}

Intermediate wheatgrass $\left(\right.$ Kernza $\left.{ }^{\circledR}\right)$ Thinopyrum intermedium $\left(5^{\text {th }}\right.$ selection cycle, Land Institute, Kansas, USA) and alfalfa Medicago sativa (cv. Creno) were sown on 11 April and 9 September 2016. Intermediate wheatgrass was grown on three research plots of $100 \mathrm{~m}^{2}$ each and alfalfa was grown on six research plots of $15 \mathrm{~m}^{2}$ each. Both crops were sown at $20 \mathrm{~kg}$ seeds/ha with a row spacing of $25 \mathrm{~cm}$. All plots were kept under rainfed conditions and plants received $100 \mathrm{~kg} \mathrm{~N} /$ ha in the form of NPK fertilizer (YaraMila 21-7-3) in early spring, every year. Crops were grown organically, mechanical weed management was carried out when necessary and no insect and disease management was performed.

\section{Measurements and monitoring}

\section{Crop growth and yield}


During the main growing season (Apr.-Oct.), crop height and phenological stages were recorded every two weeks. Alfalfa was harvested three times per year using a grass harvester, whereas intermediate wheatgrass was harvested for grains and straw at maturity, using a combine harvester. Subsamples of 200 grams of fresh weight, grain and biomass were oven-dried at $105^{\circ} \mathrm{C}$ during 48 hours for estimation of moisture content and Thousand Kernel Weight (TKW) was calculated.

\section{Soil water content}

Soil Volumetric Water Content (VWC) was monitored, as a proxy of root water uptake, using TDR sensors (Acclima $310 \mathrm{~S}$ with a $0.1 \%$ resolution, Acclima, Inc., USA). In each research plot, three sensors were installed at 0.75, 1.5 and $2.5 \mathrm{~m}$ depth. Sensors were replicated at three locations in the intermediate wheatgrass plots reaching a total of 9 sensors per depth. Replication was not possible in the alfalfa plots due to area limitations, resulting in a total of 6 sensors per depth. All sensors were at least $0.5 \mathrm{~m}$ from the plot edge and $1 \mathrm{~m}$ apart. TDR sensors were mounted on PVC pipes and inserted vertically down a pre-drilled hole. The holes were refilled with bentonite to avoid any preferential flow along the edge of the pipe. The sensor's cables were protected with PVC pipes and buried $0.3 \mathrm{~m}$ deep to protect them from rodents and to allow the use of agricultural machinery. Groundwater level was monitored using a CTD-10 sensor (Decagon, USA) in two boreholes located on the research plots. Two CR6 data loggers (Campbell Scientific, Inc., USA) collected data from the sensors at one-hour intervals.

\section{Root growth}

Seasonal root growth was monitored using 5-m deep minirhizotrons placed at a $30^{\circ}$ angle from the vertical. In the intermediate wheatgrass plots, three minirhizotron tubes were installed per plot while in the alfalfa plots only one minirhizotron tube was installed per plot due to area limitations. This makes a total of 9 and 6 minirhizotron tubes respectively in the intermediate wheatgrass and alfalfa plots. All minirhizotron tubes were installed during the winter 2015-16 and each tube was imaged on a monthly basis from May to August in 2018 and 2019 using a single multispectral camera unit mounted on an automatic minirhizotron image acquisition system (Svane et al. 2019). Root detection was performed using an automatic image segmentation method utilising a convolutional neural network (Smith et al. 2020). To validate the procedure, 2000 images were randomly selected from the entire database of images taken. Decision was taken to train the network on all root structures without distinction of living or senescing roots. Predictions of the average root length per image by the neural network were compared to average root intensity per image obtained by the grid counting method as in Thorup-Kristensen et al. (2012). Both crops had an R-square higher than 0.55, which was considered sufficient for the purpose of this study (Supplemental Fig. 2). Extra care was taken to make sure that the network would not create any false positives in the lower range of root intensity as these could significantly affect the crop rooting profile at depth. Maximum rooting depth was defined as the averaged depth of the three deepest images with a root length greater than $0.6 \mathrm{~cm}$.

\section{Deuterium tracer labelling experiment}

A deuterium labelling experiment was used to derive direct measurements of root water uptake at depth. A one-time measurement of root length density was obtained when soil cores were taken.

\section{Background information and preparation}

The deuterium tracer labelling experiment was divided in two periods, referred to as the June and the July-August period. On 13 June and 18 July 2019 respectively, one soil core was taken in three different research plots, using a standard steel auger $\left(\varnothing 7 \mathrm{~cm}\right.$, height $10 \mathrm{~mm}, 385 \mathrm{~cm}{ }^{3}$ internal volume, Eijkelkamp). Soil samples were taken from the soil surface to a maximum depth of $2.0 \mathrm{~m}$ in regular increments of $0.25 \mathrm{~m}$ and stored in ziplock bags. For each soil depth increment, three sub-samples were taken to estimate soil volumetric water content ( 300g), soil deuterium natural abundance $(\sim 20 \mathrm{~g})$ and root length density $(\sim 1.5 \mathrm{~kg})$. Soil fresh weight was measured, and samples were kept frozen prior to analysis. In each drilled hole, a PVC pipe ( $2.1 \mathrm{~m}$ in length, $\varnothing 6 \mathrm{~cm}$ ) was inserted. PVC pipes were open at the bottom to allow placement of a deuterium enriched solution at $1.9-2.0 \mathrm{~m}$ without contamination of upper soil layers. PVC pipes were perforated in their lower $10 \mathrm{~cm}$, to ensure a good flow of the tracer solution into the soil. The upper part of each pipe was covered with a PVC plug and the space around the pipes was backfilled with bentonite to prevent water infiltration along the tube.

\section{Root length density and soil volumetric water content.}

In the laboratory, root samples were obtained by manually washing them free of soil using a sieve with a mesh size of $0.5 \mathrm{~mm}$. For each soil sample collected, every root segment was retrieved from the sieve and stored at $4{ }^{\circ} \mathrm{C}$ in $70 \%$ ethanol. Roots were scanned using an Epson Perfection V700 Photo flatbed scanner at 800 dpi and analyzed for root length and mean diameter with WINRhizo software (Regent Instruments, Quebec, Canada). Soil samples were oven dried at $105^{\circ} \mathrm{C}$ for 48 hours for estimation of the gravimetric water content.

\section{Stable isotope labelling and sampling}


On 17 June and 22 July 2019, $500 \mathrm{ml}$ of a deuterium enriched tracer solution was poured down the PVC pipes $\left(\delta^{2} \mathrm{H}_{\text {June }}=300000 \%\right.$, $\delta^{2} \mathrm{H}_{\text {July- }}$ August $=600000 \%$ ). On 17 June, inflorescences were emerging for both crops. On 22 July, intermediate wheatgrass was at the soft dough stage while alfalfa was at a mid-vegetative stage (Supplemental Table 1). Separate PVC pipes were used for the two periods. Soil sampling occurred four days prior to the tracer solution injection and plant sampling started on the day of injection and then occurred at 1,4,8, 16, and 24 days after injection. Plant biomass samples were collected around 10 am, stored in a capped test tube (Pyrex, 1622/22M; Kartell Labware, ø22mm) and frozen shortly after collection. In the laboratory, leaves and stems were separated in a cold chamber prior to water extraction to account for differences in isotopic signature. Plant transpiration water was collected in the morning by placing a transparent plastic bag ( $20 \mathrm{~L}_{\text {alfalfa- }}$ $80 \mathrm{~L}_{\text {intermediate wheatgrass, }}$ Logicon Nordic A/S) over the plant shoots, tying the bag with a string creating a small gulley to prevent leakage of the transpiration water. Water was then sampled in the gulley in the afternoon around 2-3 pm. Plant biomass and transpiration water samples were taken near the tracer injection pipes and in non-impacted areas (i.e. control). Date and types of samples processed are presented in (Supplemental Table 2).

\section{Stable isotope analysis}

Water in leaf, stem and soil were extracted using a cryogenic vacuum distillation as described by Ehleringer and Osmond (1989). Transpiration water samples were filtered using filter syringes $(0.45 \mu \mathrm{m}$, FisherSci). All water samples were put into glass vials prior to analysis. Stable isotopes (i.e. $\delta^{2} \mathrm{H}$ and $\delta^{18} \mathrm{O}$ ) in water samples were analyzed using an isotopic water analyzer (L2140-i, Picarro Inc., USA). All water extraction and analyses were performed at the SilvaTech Platform, INRAE-Nancy, France. Isotope values are expressed in delta notation and calculated as followed (equation 1):

(1) $\quad \delta(\%)=\frac{\text { Rsample }}{\text { Rstandard }}-1 \times 1000$

Where Rsample and Rstandard are the ratios of the heavier to the lighter isotope of the sample and of the standard (i.e. Vienna Standard Mean Ocean Water, VSOW), respectively. In this experiment, all samples with a positive isotopic signature (i.e. threshold value corresponding to more than twice the value of the third quartile of the control samples (Fig. 5)) were considered to reflect an uptake of deuterium tracer.

\section{Modelling approach}

Simulation study was used to assess the relative root water uptake from different soil depths as well as specify seasonal differences.

\section{Model description}

The HYDRUS-1D model (version 4.17; www.pc-progress.com) was selected to simulate the 1-dimensional flow of soil water under saturated and unsaturated conditions and plant water uptake (Šimůnek et al. 2009). HYDRUS-1D numerically solves the Richards equation under variable soil water conditions with a sink term that represents plant water uptake. Main equations behind the model functioning are provided in supplementary material "Hydrus-1D Model functioning and equations". For more information on Hydrus-1D see (Šimůnek et al. 2009).

\section{Parametrisation of Hydrus-1D}

The model was run for the years 2018 and 2019 with atmospheric conditions as upper boundary conditions. Reference evapotranspiration was calculated on an hourly basis using the Penman-Monteith equation (Allen et al. 2006). Crop potential evapotranspiration was calculated by applying a crop factor to the reference evapotranspiration (Allen and Pereira 1998). Hydrus-1D requires potential soil evaporation and crop transpiration to be specified as separate inputs. To do so, the Beer's law method was used to partition potential evapotranspiration into potential transpiration and evaporation fluxes based on the leaf area index (Sutanto et al. 2012). Leaf area index was calculated based on crop height for alfalfa and crop stages for intermediate wheatgrass using equations from Allen et al. (1989) and Mitchell et al. (1998), respectively (Supplemental Table 1). A variable pressure head was used as lower boundary conditions based on the measured groundwater level. Calculation methods of actual transpiration, evaporation and root water uptake are provided in supplementary material "Hydrus-1D Model functioning and equations". Initial conditions were set to complete saturation of the soil profile, at the beginning of each year, which is normally the case at the study site (Fig. 2).

The soil profile was set to $2.5 \mathrm{~m}$ and divided in two simplified layers (i.e. top layer: 0-0.75 m and bottom layer: 0.75-2.5 m). According to equation 4 and 8 (supplementary material "Hydrus-1D Model functioning and equations"), the total number of parameters describing soil hydraulic properties

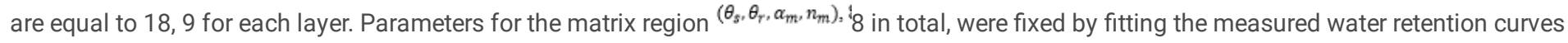
(Supplemental Fig. 1). The remaining 10 parameters $\left(2 x\left[K_{s}, \tau, \alpha_{f}, n_{f}, w_{f}\right]\right)$ were estimated by means of inverse modelling (Hopmans and Šimůnek 1999$)$ and by minimising the objective function: 
(2) $\quad O(p)=\sum_{i=1}^{n n}\left(\theta_{\exp }-\hat{\theta}\right)^{2}$

where $p$ is the unknown parameter vector, $\left[K_{s}^{\text {top }}, \tau_{f}^{\text {top }}, a_{f}^{\text {top }}, n_{f}^{\text {top }}, w_{f}^{\text {top }}, K_{s}^{\text {bot }}, \tau_{f b t}^{\text {bot }}, a_{f}^{\text {bot }}, n_{f}^{\text {bot }}, w_{f}^{\text {bot }}\right], n n$ is the total number of TDR measurements at three depths, and $\theta_{\exp }$ and $\theta$ are measured and simulated water content values, respectively. Superscripts top and bot refer to top and bottom soil layers.

Parameter adjustment was performed for each crop type and compensation level to improve the fit of each model assuming subtle soil differences related to soil texture and cropping history. We used the Levenberg-Marquart algorithm (Marquardt 1963) for minimising equation 2, as implemented in Hydrus-1D. Parameter uncertainty was estimated by using the first-order second moment method (Diamantopoulos et al. 2012).

Root water uptake parameters were obtained from an existing database, Taylor and Asshcroft (1972) for alfalfa and parameters for wheat were obtained from Wesseling (1991) and applied to intermediate wheatgrass. Respective values are summarized in Table 2. Crop rooting profile was fixed for the whole simulation based on the average root length density distribution obtained from the soil coring method in 2019 (Fig. 4 ).

In Hydrus-1D a compensatory water uptake function is used to reflect compensatory water uptake that occurs under topsoil drying (Jarvis 1989; supplementary material "Hydrus-1D Model functioning and equations"). Little is known about the compensatory water uptake threshold ( $\omega_{\mathrm{c})}$ and how it varies between crops (Skaggs et al. 2006). Decision was taken to run the model for different values of $\omega_{\mathrm{c}}$ found in the literature (i.e. 0.1 , $0.75,0.875$ and 1.0) and discuss the relevance of the results and of the compensation effect (Skaggs et al. 2006; Simunek and Hopmans 2009; Mazzacavallo and Kulmatiski 2015). For each crop type (i.e. alfalfa and intermediate wheatgrass), four compensation scenarios (i.e. 0.1, 0.75, 0.875 and 1.0) were investigated. A total of 8 simulations were carried out. All fixed and fitted parameters are listed in Table 2 and supplementary Table 3 .

\section{Data analysis}

All statistical tests were performed using the $R$ software using the Rstudio interface (version $1.1 .383 ; R$ core team, 2018) using the "Ime4, version 1.1-21", "multcomp, version 1.4-10", "ggplot2, version 3.1.0" and "emmeans, version 1.4.3.01" packages. We used linear mixed models to look for variations in soil volumetric water content, root length, root length density and soil deuterium natural abundance with soil depth. Normality and homoscedasticity of the data were checked by looking at the residuals and Q-Qplot. When data did not fulfill these two assumptions, a log transformation was applied to normalize the data. Differences between stomatal conductance, biomass, grain yield, TKW, water samples $\delta^{2} \mathrm{H}$ and $\delta^{18} \mathrm{O}$ between crops and sample types were tested using pairwise comparisons of means with Tukey-adjusted p-values.

\section{Results}

\section{Crop performance}

Although exposed to different climatic conditions, we did not find any significant differences in grain yield between the two years for intermediate wheatgrass although differences in TKW were observed (Table 3). For alfalfa, harvested biomass was significantly lower in June 2018 than 2019 but no differences were found for the August and October harvests (Table 3). These results suggest that both crops were more water limited during the spring-summer 2018 compared to 2019 although direct measurements have not been carried out.

\section{Development and intensity of root growth}

Both crops developed a deep root system (>1.0m) (Fig. 3). Maximum rooting depth from minirhizotron measurements was estimated at $2.0 \mathrm{~m}$ in August 2018 for both crops and at 2.8 and $2.5 \mathrm{~m}$ in August 2019 for alfalfa and intermediate wheatgrass, respectively (Fig. 3d). Along minirhizotron tubes, root length of intermediate wheatgrass decreased with soil depth whereas root length of alfalfa peaked between 0.75 and 1.75 $\mathrm{m}$ depth. In 2018, intermediate wheatgrass had significantly greater root length at $0.5,1.0$ and $1.25 \mathrm{~m}$ soil depth in May and at $1.0 \mathrm{~m}$ soil depth in June compared to 2019. No differences were found in July, but greater root length was observed at $0.25 \mathrm{~m}$ soil depth in August 2018 compared to 2019. Alfalfa had significantly lower root length in 2018 compared to 2019, particularly within the first $1.5 \mathrm{~m}$ depth of soil. Significant differences were observed during the months of May, July and August. Interestingly greater root length was observed at $1.75 \mathrm{~m}$ soil depth in July and August 2019 compared to 2018. In both years, alfalfa had greater root length than intermediate wheatgrass in the $0.75-1.75 \mathrm{~m}$ soil depth interval.

Root length density, obtained from soil cores taken in the spring-summer 2019, decreased with soil depth for both crops (Fig. 4a). Intermediate wheatgrass had more roots in the topsoil than alfalfa with significant differences at 0.25 and $0.75 \mathrm{~m}$ soil depth (Fig. $4 \mathrm{a}$ ). Intermediate wheatgrass had more coarse roots (i.e. diameter $>1 \mathrm{~mm}$ ) in the topsoil layer (i.e. $0.25 \mathrm{~m}$ ) while alfalfa had a higher number of coarse roots at depth (i.e. $>0.5 \mathrm{~m}$ depth) with significant differences at $0.5 \mathrm{~m}$ and $1.0 \mathrm{~m}$ soil depth (Fig. 4b). Both crops had similar root length density in deep soil layers with on average $0.4 \mathrm{~cm} / \mathrm{cm}^{3}$ between 1.5 and $2.0 \mathrm{~m}$, but alfalfa tended to have higher root length density at 1.75 and $2.0 \mathrm{~m}$. However, no statistical differences were apparent and root length density was highly variable at those depths.

Page 6/24 


\section{Soil moisture patterns}

Both seasons gave similar results in terms of dynamics of soil moisture content at $0.75,1.5$ and $2.5 \mathrm{~m}$ but crop differences were identified (Fig. $2 \mathrm{ab})$. In 2018, soil water content at $0.75 \mathrm{~m}$ soil depth started to decrease in June for both crops. Water depletion was relatively fast and by July this soil layer was dry ( 18\% VWC; pF>3.0) under both crops. In 2019, soil water depletion at $0.75 \mathrm{~m}$ started approximately one month earlier in May. At $1.5 \mathrm{~m}$ soil depth, soil water depletion started around July but showed contrasting patterns between the two crops. Alfalfa depleted this soil layer down to $25 \% \mathrm{VWC}(\sim \mathrm{pF}=2.8)$ whereas under intermediate wheatgrass the soil water content never dropped below $29 \% \mathrm{VWC}(\sim \mathrm{pF}=2.0)$. As observed at $0.75 \mathrm{~m}$, water uptake at $1.5 \mathrm{~m}$ soil depth under alfalfa started about a month earlier in 2019 during the month of June. In August 2018 , soil moisture content at $0.75 \mathrm{~m}$ depth increased to $24 \%$ for both crops due to rainfall events. Soil moisture content further decreased until October under alfalfa but no decrease was observed under intermediate wheatgrass. These results show that both crops induced changes in soil water content down to $1.5 \mathrm{~m}$ depth but that alfalfa extracted more water at depth than intermediate wheatgrass. Small reductions in soil water content ( 1-2\% VWC) were observed at $2.5 \mathrm{~m}$ around July in both years for alfalfa but no soil water extraction was observed under intermediate wheatgrass. These observations were supported by groundwater levels measured near the study plots in mid-august (Fig. $2 \mathrm{c}$ ). In a well adjacent to the alfalfa plots, the groundwater level dropped down to $3 \mathrm{~m}$ and more than $3.5 \mathrm{~m}$ in 2018 and 2019, respectively. In contrast, in a well near the intermediate wheatgrass plots, the groundwater level only dropped to 2.5 and $2 \mathrm{~m}$ depth in 2018 and 2019 , respectively. During the winter period, groundwater dynamics under both crops were similar.

\section{Deuterium tracer labelling experiment}

Deuterium tracer uptake in alfalfa samples were observed on 21 and 24 June, on the 11, 27,29 July and on 7 August 2019 (Fig. $5 a$ ). Even though the deuterium tracer concentration was doubled during the July-August period, no increase in tracer uptake was detected on the samples' isotopic signatures. The highest deuterium signatures were obtained in leaf and stem samples $\left(\delta^{2} \mathrm{H}=913 \%\right.$ and $\delta^{2} \mathrm{H}=990 \%$, respectively) on $24 \mathrm{June}$ 2019. In the case of intermediate wheatgrass, a positive isotopic signature ( $\delta^{2} \mathrm{H}=13 \%$ ) was observed solely on $7^{t}$ August 2019 . This highlights the capacity of intermediate wheatgrass to take up water from $2.0 \mathrm{~m}$ soil depth but in much smaller amounts than alfalfa (i.e. alfalfa's enrichment values were almost 100 times higher). In this study, deuterium tracer labelling was used to detect direct root water uptake at depth. It was not possible to obtain a quantitative estimate of the root water uptake, as this would require additional information (e.g. plant fractionation level) and the establishment of a soil-water-tracer flux model.

\section{Modelling approach}

\section{Simulation of soil hydraulic parameters and soil water content}

The soil hydraulic parameters adjusted by inverse modelling allowed an effective prediction of the soil water movement for both crops (RMSE= $0.01 ; R^{2}>0.60$ ) under different compensation scenarios (Table 4). This conclusion can be drawn because, first, the fitted soil water retention curves match the measured values well and are similar across simulations (Supplemental Fig. 1). Small differences in soil water retention curves were predicted for the bottom layers which suggest a plot/crop effect. Second, the fitted soil conductivity curves are also similar across simulations (Supplemental Fig. 4). Third, over the two years' time course, the different simulations predicted the soil volumetric water content evolution relatively well: gradual decrease of the soil water in the spring and replenishment of the soil profile in the autumn (Supplemental Fig. 5). However, some discrepancies from these statements are noticeable. In particular, the soil profile was re-wetted earlier in November 2018 for all simulations compared to the measured values (Supplemental Fig. 5). In addition, the worst model predictions were obtained for the simulation of intermediate wheatgrass with a full compensation $\left(\omega_{\mathrm{c}}=0.1\right)$ as the simulated soil water content at $0.75 \mathrm{~m}$ dropped much lower than the measured values (Supplemental Fig. 5) and the soil conductivity curve in the topsoil showed higher values than others simulations (Supplemental Fig. 4). Nevertheless, the soil fitted parameters and simulated values of soil water content closely match the measured values, suggesting that the models accurately described water movement at the soil-plant and field level. Given the limited amount of measured data (i.e. drying cycle at only two soil depths and a single measured retention curve), some degree of variation is expected. Nonetheless, simulations with low compensation levels (i.e. $0.75,0.875,1)$, presented results of root water uptake and plant transpiration within a similar range (Fig. 6; Supplemental Fig. 6). In conclusion, these models are suitable for the purpose of this study, which was to provide an estimate (i.e. range) of the contribution of deep soil layers to the crop transpiration. All simulation results are presented on a yearly basis. Herbaceous plants are expected to have a compensation factor of around 0.75 (Simunek and Hopmans 2009). Therefore, simulations with a compensation factor of 0.75 are presented on a monthly basis.

\section{Root water uptake profiles}


For all simulations, alfalfa showed higher evapotranspiration due to its longer growing season and higher crop factor. Alfalfa used more water from deep soil layers (>1 m) compared to intermediate wheatgrass (Fig. 6ab). For both crops, actual transpiration was lower than the potential transpiration except for the simulation with a full compensation (i.e. $\omega_{c}=0.1$ ) suggesting that crops had been water limited under all other scenarios. All simulations with a limited compensation (i.e. $\omega_{c}=0.25,0.5$ and 0.75 ) showed higher water limitation in 2018 than 2019 . When considering all the scenarios, alfalfa used annually between 68 to $157 \mathrm{~mm}$ from the $1.0-1.5 \mathrm{~m}$ layer covering 20 to $30 \%$ of the plant transpiration and between 13 to $53 \mathrm{~mm}$ from the $1.5-2.0 \mathrm{~m}$ layer covering respectively 4 to $10 \%$ of the plant transpiration. In comparison, intermediate wheatgrass had a lower water uptake with 28 to $123 \mathrm{~mm}$ taken annually from the $1.0-1.5 \mathrm{~m}$ layer covering 9 to $27 \%$ of the plant actual transpiration. From the $1.5-2.0$ m layer, intermediate wheatgrass used between 4 to $27 \mathrm{~mm}$ annually covering 1 to $6 \%$ of the plant actual transpiration.

When focusing on the scenario with a moderate compensation level (i.e. $\omega_{c}=0.75$ ), the monthly water uptake profile differs between the two crops and the two years (Fig. 7ab). For both crops, actual transpiration was lower than the potential transpiration in June, July and August 2018 suggesting that the plants had been particularly water limited during those months. Under wetter conditions (i.e. 2019), intermediate wheatgrass used more water from the 0-0.5 m soil layer compared to alfalfa. However, during both growing seasons both crops tended to take up similar amounts of water from the 0.5-1.0 soil layer (Fig. 7). For both crops, the contribution of deep water increases during the season with a peak around July. In July 2018, alfalfa used approximately $28 \mathrm{~mm}$ and $8 \mathrm{~mm}$ respectively from the 1.0 to $1.5 \mathrm{~m}$ and 1.5 to $2.0 \mathrm{~m}$ layers against $16 \mathrm{~mm}$ and 4 $\mathrm{mm}$, respectively in 2019. During this particularly dry month, the relative contribution of deep water to plant transpiration was more than doubled in comparison to 2019 and reached $47 \%$ and $13 \%$ respectively for the 1.0 to $1.5 \mathrm{~m}$ and 1.5 to 2.0 m layers. In comparison, in July 2018 , intermediate wheatgrass used $12 \mathrm{~mm}$ and $3 \mathrm{~mm}$ of water from the 1.0 to $1.5 \mathrm{~m}$ and 1.5 to $2.0 \mathrm{~m}$ layers, respectively against $9 \mathrm{~mm}$ and $2 \mathrm{~mm}$ in July 2019 . However, deep water used from the 1.0 to $1.5 \mathrm{~m}$ and 1.5 to $2.0 \mathrm{~m}$ layers still contributed up to $34 \%$ and $8 \%$ of the plant transpiration in July 2018 . Furthermore, our simulation results showed relevant water uptake after anthesis for intermediate wheatgrass with 30 and $22 \mathrm{~mm}$ from the $1.0 \mathrm{~m}$ 2.0 m layer in 2018 and 2019, respectively.

\section{Discussion}

This study provides empirical evidence that both crops grow roots below $2.0 \mathrm{~m}$ soil depth that are capable of taking up water. However, the two crops still presented different soil exploration strategies and water acquisition capacities. This is important since the identification of root phenotypes linked to deep root growth and activity are important tools for the selection and breeding of crops with greater drought tolerance (Lynch 2018).

\section{Crop rooting profile}

We found that both crops developed fine roots deeper than $2.0 \mathrm{~m}$ as found in other studies (Dardanelli et al. 1997; Ward et al. 2002; Cox et al. 2006). Overall, alfalfa was deeper rooted and presented a higher proportion of roots at depth compared to intermediate wheatgrass.

For intermediate wheatgrass, root length was highest in the topsoil (i.e. $>0.5 \mathrm{~m}$ ) and root density decreased steeply with soil depth as observed in others studies (Sprunger et al. 2018; Pugliese et al. 2019). Minirhizotron measurements showed that intermediate wheatgrass presented lower root length in the topsoil layers in May 2019, most likely in response to the very dry April month during that year. Apart from this, no clear difference in rooting profile was observed between the two years, suggesting that the drought of 2018 had little effect on root growth. This lack of differences between the two years also suggests a high rate of root turnover. This could be due to new roots being established each year, most likely from newly formed tillers or/and to water-saturated conditions in winter that lead to root die back (Herzog et al. 2016). In fact, it is still unclear which portion of the root system of intermediate wheatgrass remains active over time and especially after harvest, which should require particular attention (Cox et al. 2006). Nevertheless, the coring method reinforced the idea that intermediate wheatgrass had interesting characteristics in terms of deep rooting with higher root length density below $1.5 \mathrm{~m}$ soil depth than previously reported for spring and winter wheat (Gregory et al. 1979; Kirkegaard et al. 2007).

With more than $20 \%$ of the plant total root length below $1.0 \mathrm{~m}$, alfalfa had deeper and more evenly distributed roots throughout the soil profile than intermediate wheatgrass. For alfalfa, peaks in root length identified within the $0.75-1.75 \mathrm{~m}$ soil layer along minirhizotron tubes suggest that roots grew preferentially at depth and that over time alfalfa gradually builds a deeper root system (Pietola and Smucker 1995). The fact that alfalfa presented lower root length along minirhizotron tubes in 2018 in comparison to 2019, suggests that roots grow deeper from older roots or/and that root growth was hampered by the particular dry condition of that year (Sheaffer et al. 1988; Erice et al. 2010). We did not find roots deeper than $3 \mathrm{~m}$ for alfalfa, as reported by Borg and Grimes (1986). In fact, at this location, root growth of both crops was most likely hampered by the high soil bulk density encountered in the subsoil and saturated water conditions during part of the winter. Tap-rooted species like alfalfa have a higher penetration capacity of highly compacted soil layers due to greater root diameter when compared to fibrous rooted species like intermediate wheatgrass (Materechera et al. 1992). Dicotyledonous crops, such as alfalfa, may also have a better tolerance to waterlogging conditions than monocotyledonous crops, such as intermediate wheatgrass, due to secondary thickening of their root tissue which reduces oxygen loss, as hypothesized by Strock and Lynch (2020). Both crops had a deeper root system in 2019, when the groundwater level was lower. 


\section{Root water uptake}

All methodological approaches indicated that alfalfa was taking up more water from deep soil layers than intermediate wheatgrass and allowed us to conclude that both crops were capable of taking water down to $2 \mathrm{~m}$ soil depth. Overall, model simulations showed that alfalfa took approximately twice as much water as intermediate wheatgrass below $1.0 \mathrm{~m}$ soil depth. Crop differences in deep water uptake are likely to be due to differences in (1) root distribution, (2) crop water demand and (3) root hydraulic conductivity at depth (Clément 2021; Strock et al. 2021). Firstly, the spatial distribution of roots in the soil influences the development of the soil water potential and of the plant response (e.g. ABA) (Draye et al. 2010). In fine textured soil like in this study, high root length density in the topsoil will induce a rapid drop of the soil water potential and thus force intermediate wheatgrass to rely on fewer roots at depth. In contrast, alfalfa whose root distribution decreases less exponentially with soil depth might present a more homogeneous water uptake throughout its root zone. Secondly, alfalfa presented a higher stomatal conductance (data not shown) and transpiration, especially because transpiration of cereals decreases during the reproductive stage (Allen and Pereira 1998). Finally, alfalfa presented a larger amount of coarse roots at depth compared to intermediate wheatgrass. Coarse roots with more abundant metaxylem vessels will have a higher axial hydraulic conductance favouring plant water uptake from deeper soil layers compared to cereals with finer roots (Hamblin and Tennant 1987; Zwieniecki et al. 2003). Considering that alfalfa is known to be able to extensively deplete the soil water profile, down to $10 \mathrm{~m}$ depth in some cases (Li and Huang 2008), it is likely that, in this study, rooting depth and water uptake of alfalfa were limited by soil constraints and climatic conditions. Intermediate wheatgrass is known for taking up more water from the 0.5-1.0 m soil layer than annual wheat (Culman et al. 2013; Sprunger et al. 2018) and other perennial grasses (Sainju et al. 2017). Our results concord with such findings as intermediate wheatgrass was as efficient as alfalfa in taking up water from the first meter of soil and even more efficient in the topsoil layers (i.e. $<0.25 \mathrm{~m})$.

Simulation results and TDR sensor measurements showed that for both crops, deep water uptake increased from April to July. This increase occurred during critical stages and during the driest month of the growing season which makes it of great importance to maintain yield under dry conditions (Kirkegaard et al. 2007; Lilley and Kirkegaard 2011). These findings highlight the role that root length at depth plays in mitigating drought impact but root length is not the sole driver behind water uptake (Hamblin and Tennant 1987). In particular, deep root water uptake depends on the crop water demand, hydraulic conductivity and compensation effects that occur at the plant level (Jarvis 1989; Skaggs et al. 2006; Simunek and Hopmans 2009). However, estimating the plant hydraulic conductivity and the extent to which compensation occurs at the plant level remain highly challenging when modelling root water uptake (Cai et al. 2017). Under a scenario of nearly full compensation $\left(\omega_{c}=0.1\right)$ plants did not experience water limitation. However, such a scenario does not match our crop measurements and model fit was lower under this scenario. As speculated by Simunek and Hopmans (2009), it is more likely that herbaceous plants have lower compensation levels of around $\omega_{\mathrm{c}}=0.75$ which is in line with results from (Cai et al. 2017) on winter wheat. Although passive compensation had certainly taken place through redistribution of hydraulic pressure within the plant, our data do not support the idea of active compensation under drought (i.e. development of roots in wet soil layers) as reported for other crops like chicory (Vandoorne et al. 2012).

When looking at the TDR measurements, alfalfa used more water from the deep soil layers in 2019 compared to 2018. In contrast, intermediate wheatgrass used similar amounts of water from the deep soil layers in both years. This is supported by minirhizotron measurements that showed that alfalfa had more root at depth in 2019 than in 2018 and that intermediate wheatgrass had similar amount of roots at depth in both years. Groundwater level was also lower below the alfalfa plot in 2019 than in 2018. However, model simulations predicted higher deep water uptake in 2018 than in 2019 for both crops and that the relative contribution of deep soil layers to plant transpiration was more than doubled in 2018 compared to 2019 during dry months. In this study, a main limitation comes from the fact that the model uses a fixed root distribution along the soil profile to derive root water uptake, which disregards the dynamics of root growth (Vadez 2014). In our case, using a fixed root distribution for both years based on measurements done in 2019 constitutes a non-realistic assumption that restricts our simulation based conclusion on root water uptake in 2018. In consequence, model simulations likely overestimate the capacity of crops to uptake water from deep soil layers in 2018 due to greater root length at depth in 2019. However, this approach is still relevant to estimate the contribution of deep subsoil layers to the plant transpiration and to study the role that root length at depth could play under drought conditions. Further differences between the Hydrus-1D and the TDR sensors readings could also be due to (1) root length density in the vicinity of the sensors, (2) the soil structure around the sensor and (3) the prediction accuracy of the plant phenological development (Duchene et al. 2021). Nonetheless, simulated soil water retention and conductivity curves and soil water content were well correlated to measured observations at specific depths, which allow us to conclude that this model provides relevant results on deep root water uptake of these two perennial crops.

\section{Deuterium tracer labeling experiment}

Results obtained from the tracer labelling study suggest a much bigger difference in root water uptake at $2.0 \mathrm{~m}$ between alfalfa and intermediate wheatgrass than results obtained with TDR sensors and simulation work. One explanation for this difference could be that the soil conditions at the time of injection have a great influence on the tracer movement. At the time of injection the $2.0 \mathrm{~m}$ soil layer under alfalfa was drier than under intermediate wheatgrass. In addition, the groundwater level was also lower in the alfalfa plot than in the intermediate wheatgrass plot (Fig. 2c). For 
intermediate wheatgrass, such wetter conditions could have favored the diffusion and dilution of the tracer solution within the soil water and limited root activity due to anoxic conditions.

Without labelling, the isotopic signature of the soil water varied with soil depth and aboveground crop type (Fig. 4c). Soil water isotopic signature was significantly more depleted under intermediate wheatgrass at 0.5 and $0.75 \mathrm{~m}$ soil depth compared to alfalfa. A similar though non-significant trend was observed at $1.5 \mathrm{~m}$. Significant differences in soil water isotopic signatures seems to coincide with differences in root length density between the two crops (Fig. 4ac). For four soil layers (i.e. $0.25,0.5,0.75$ and $2.0 \mathrm{~m}$ ), the correlation between root length density and soil water isotopic signature had $\mathrm{R}^{2}$ values higher than 0.4 (Supplemental Fig. 3a). The fact that correlation within soil layers is higher than the overall correlation (i.e. $\mathrm{R}^{2}=0.29$ without soil layer distinction) for 6 layers out of 8 , indicates a soil depth effect. The correlation between root length density and the soil isotopic signature suggested that roots, by modifying the soil water cycle, influence the soil isotopic signature. At the study site, rainfall has different isotope signatures depending on the season (Supplemental Fig. 3a) and therefore deeper soil layers will be replenished with water having a different isotopic signature than shallower ones (Gazis and Feng 2004; Nielsen et al. 2010). Roots, by altering the water cycle in their surrounding soil layer, are changing the isotopic signature of the soil by allowing its replenishment from rainfall of a different isotopic signature. The enrichment in heavy isotope in the topsoil was most likely due to equilibrium fractionation that occurs during evaporation and replenishment of the topsoil layer by enriched summer rainfall. In subsoil layers, it is supposed that higher root length density will remove substantial amounts of soil water and allow replenishment of the soil layers with more depleted autumn and winter rainfalls as illustrated by the soil moisture patterns (Fig. 2).

\section{Crop performance and water limitation}

Harvested biomass, TKW and simulation results indicated that both crops experienced water limitation in 2018. For intermediate wheatgrass, the dry spring of 2018 restricted vegetative development before the reproductive phase which favoured the formation of fewer but larger grains compared to 2019 (Korte and Chu 1983; Blum et al. 1990). In perennial grasses, grain yield varies over years and usually peaks during the $2^{\text {nd }}$ or $3^{\text {rd }}$ years and then declines (Wagoner 1990). High variability in intermediate wheatgrass grain yields is found in the literature with second year yield ranging between 0.4 and 1.7 t/ha depending on climate, environmental conditions, farming management and selection lines (Culman et al. 2013; Pugliese et al. 2019). While our second- and third year yield fall within this range, it is possible that a yield reduction occurred in 2018 due to drought, but that is masked by the difference in yield potential between years. For alfalfa, yield from the June harvest was significantly lower in 2018 than in 2019 suggesting an effect of the dry 2018 spring. Harvested biomass of the two later cuts were very similar between years and annual forage yields are in line with the yield range found in the literature (i.e. 10 - 20 t/ha) (Riday and Brummer 2002).

\section{Conclusion}

In this study intermediate wheatgrass and alfalfa used water from deep soil layers (i.e. $2.0 \mathrm{~m}$ ) due to their extensive root system. Intermediate wheatgrass had a lower proportion of roots below $1.5 \mathrm{~m}$ soil depth in comparison to alfalfa. Intermediate wheatgrass also used less water from below $1.0 \mathrm{~m}$ soil depth than alfalfa.

Model simulations predicted that alfalfa used twice as much water below $1.0 \mathrm{~m}$ soil depth than intermediate wheatgrass. Nonetheless, intermediate wheatgrass was predicted to use more than $20 \mathrm{~mm}$ of water from below $1.0 \mathrm{~m}$ soil depth after anthesis in both years, showing the value of deep rooting.

During the dry conditions of 2018, alfalfa had a lower proportion of root at depth and used less water at depth than in 2019 . For intermediate wheatgrass, no clear differences were observed between the two years.

Like alfalfa, intermediate wheatgrass has the potential to exploit deep soil water, which is particularly beneficial in regions where soil water availability is high and groundwater recharge is important. The road to a profitable perennial cereal crop is still long, but having a deep root system appears to be an essential trait for breeding intermediate wheatgrass (Kernza ${ }^{\circledR}$ ) cultivars for improved drought tolerance.

Applying common root research methods to deep soil layers is challenging, but combining methods allows for a better understanding of the environmental variability and of plant adaptations to it.

\section{Declarations}

\section{Acknowledgements}

The authors would like to thank Allan Esben Hansen, Jason Allen Teem and Anders Kristian Nørgaard for technical help in the field with installation of infrastructures and data collection, to Niels Alvin Faircloth Olsen for facilitating the image processing, to Eva Rosenqvist for lending us research equipment, to Nicolas Angeli, Loic Louis and Damien Bonal for fruitful discussions and help in designing and processing the water isotopes 
samples and to Fulai Liu and Tomke Susanne Wacker for fruitful discussions and support during this study. The authors would like to thank John Kirkegaard and Kirsten Verburg for their valuable comments on the manuscript.

\section{Funding}

This research was funded by the Villum Foundation (DeepFrontier project, grant number VKR023338).

\section{Conflicts of Interest}

The authors declare no conflict of interest.

\section{Availability of data and material}

Data are available upon request to the corresponding author.

\section{Author Contributions}

CC, DBD, SFS and KTK conceived and designed the study. CC collected the data with assistance from JS on the isotope and soil coring campaign. JS and ED implemented the HYDRUS-1D model. AGS and CC analysed the minirhizotron images. CC analysed the data and wrote the paper with guidance from ED, DBD, and KTK. All authors reviewed and approved the manuscript.

\section{References}

Ahmed MA, Kroener E, Holz M, et al (2014) Mucilage exudation facilitates root water uptake in dry soils. Funct Plant Biol 41:1129-1137. doi: 10.1071/FP13330

Ahmed MA, Passioura J, Carminati A (2018) Hydraulic processes in roots and the rhizosphere pertinent to increasing yield of water-limited grain crops: a critical review. J Exp Bot 69:3255-3265. doi: 10.1093/jxb/ery183

Allen RG, Jensen ME, Wright JL, Burman RD (1989) Operational Estimates of Reference Evapotranspiration. Agron J 81:650-662. doi: 10.2134/agronj1989.00021962008100040019x

Allen RG, Pereira LS (1998) Crop evapotranspiration - Guidelines for computing crop water requirements - FAO Irrigation and drainage paper 56

Allen RG, Pruitt WO, Wright JL, et al (2006) A recommendation on standardized surface resistance for hourly calculation of reference ETo by the FA056 Penman-Monteith method. Agric Water Manag 81:1-22. doi: 10.1016/j.agwat.2005.03.007

Angers DA, Caron J (1998) Plant-induced changes in soil structure: Processes and feeedbacks. Biogeochemistry 42:55-72

Angus JF, Gault RR, Peoples MB, et al (2001) Soil water extraction by dryland crops, annual pastures, and lucerne in south-eastern Australia. Aust J Agric Res 52:183-192

Baskerville GL, Emin P (1969) Rapid Estimation of Heat Accumulation from Maximum and Minimum Temperatures. Ecology 50:514-517

Blum A, Ramaiah S, Kanemasu ET, Paulsen GM (1990) Wheat recovery from drought stress at the tillering stage of development. F Crop Res 24:67-85

Borg H, Grimes DW (1986) Depth Development of Roots with Time: An Empirical Description. Am Soc Agric Eng 29:194-197. doi: $10.13031 / 2013.30125$

Bremner PM, Fazekas de St. Groth C (1986) A Field Comparison of Sunflower (Helicanthus annuus) and Sorghum (Sorghum bicolor) in a Long Drying Cycle. I. Water Extraction. Aust J Agric Res 37:483-493

Cai G, Vanderborght J, Couvreur V, et al (2017) Parameterization of Root Water Uptake Models Considering Dynamic Root Distributions and Water Uptake Compensation. Vadoze Zo J 17:160125. doi: 10.2136/vzj2016.12.0125

Clément C (2021) Deep water uptake of perennial crops. A case study on intermediate wheatgrass and alfalfa. University of Copenhagen, Denmark Clément C, Schneider Hannah M DDB, P LJ, Kristian T-K Root and xylem anatomy varies with root length, root order, soil depth, and environment in intermediate wheatgrass Thinopyrum intermedium and Alfalfa Medicago sativa. F Crop Res

Cox TS, Glover JD, Van Tassel DL, et al (2006) Prospects for Developing Perennial Grain Crops. Bios 56:649-659 
Crews TE, Blesh J, Culman SW, et al (2016) Going where no grains have gone before: From early to mid-succession. Agric Ecosyst Environ 223:223-238. doi: 10.1016/j.agee.2016.03.012

Crews TE, Dehaan LR (2015) The Strong Perennial Vision: A Response. Agroecol Sustain Food Syst 39:500-515. doi: $10.1080 / 21683565.2015 .1008777$

Culman SW, Snapp S, Ollenburger M, Basso B (2013) Soil and Water Quality Rapidly Responds to the Perennial Grain Kernza Wheatgrass. Agron J 105:735-744. doi: 10.2134/agronj2012.0273

Cutforth HW, Angadi S V, McConkey BG, et al (2009) Comparing plant water relations for wheat with alternative pulse and oilseed crops grown in the semiarid Canadian prairie. Can J Plant Sci 89:823-835. doi: 10.4141/CJPS08138

Dardanelli JL, Bachmeier OA, Sereno R, Gil R (1997) Rooting depth and soil water extraction patterns of different crops in a silty loam haplustoll. F Crop Res 54:29-38. doi: 10.1016/S0378-4290(97)00017-8

Dehaan L, Christians M, Crain J, Poland J (2018) Development and Evolution of an Intermediate Wheatgrass Domestication Program. Sustainability 10:1-19. doi: 10.3390/su10051499

Dezsi Ş, Mîndrescu, Petrea D, et al (2018) High-resolution projections of evapotranspiration and water availability for Europe under climate change. Int J Climatol 38:3832-3841. doi: 10.1002/joc.5537

Diamantopoulos E, Iden SC, Durner W (2012) Inverse modeling of dynamic nonequilibrium in water flow with an effective approach. Water Resour Res 48:1-16. doi: 10.1029/2011WR010717

Draye X, Kim Y, Lobet G, Javaux M (2010) Model-assisted integration of physiological and environmental constraints affecting the dynamic and spatial patterns of root water uptake from soils. J Exp Bot 61:2145-2155. doi: 10.1093/jxb/erq077

Duchene O, Dumont B, Cattani DJ, et al (2021) Process-based analysis of Thinopyrum intermedium phenological development highlights the importance of dual induction for reproductive growth and agronomic performance. Agric For Meteorol 301-302:108341. doi:

10.1016/j.agrformet.2021.108341

Durner W (1994) Hydraulic conductivity estimation for soils with heterogeneous pore structure. Water Resour Res 30:211-223

Ehleringer JR, Osmond CB (1989) Stable isotopes. In: Plant Physiological ecology. pp 281-300

Erice G, Louahlia S, Irigoyen JJ, et al (2010) Biomass partitioning, morphology and water status of four alfalfa genotypes submitted to progressive drought and subsequent recovery. J Plant Physiol 167:114-120. doi: 10.1016/j.jplph.2009.07.016

FAO (2013) Perennial Crops for Food Security Proceedings of the FAO Expert Workshop

FAO (2006) Guidelines for soil description

Feddes RA, Raats PAC (2004) Parameterizing the soil - water - plant root system. In: Feddes, R.A., de Rooij, G.H., van Dam, J.C. (Eds.), Proceedings of the Unsaturated Zone Modelling: Progress, Challenges and Applications.

Fischer RA, Connor DJ (2018) Issues for cropping and agricultural science in the next 20 years. F Crop Res 222:121-142. doi:

10.1016/j.fcr.2018.03.008

Fukai S, Cooper M (1995) Development of drought-resistant cultivars using physio-morphological traits in rice. F Crop Res 40:67-86

Gazis C, Feng X (2004) A stable isotope study of soil water: evidence for mixing and preferential flow paths. Geoderma 119:97-111. doi: $10.1016 /$ S0016-7061(03)00243-X

Gregory PJ, McGowan M, Biscoe PV, Hunter B (1979) Water relations of winter wheat. J Agric Sci 93:494. doi: 10.1017/S0021859600038223

Hamblin A, Tennant D (1987) Root Length Density and Water-Uptake in Cereals and Grain Legumes - How Well Are They Correlated. Aust J Agric Res 38:513-527

Herzog M, Striker GG, Colmer TD, Pedersen O (2016) Mechanisms of waterlogging tolerance in wheat - a review of root and shoot physiology. Plant Cell Environ 39:1068-1086. doi: 10.1111/pce.12676

Hopmans JW, Šimůnek J (1999) Review of inverse estimation of soil hydraulic properties. In: Proceedings of the International Workshop on Characterization and Measurements of the Hydraulic Properties of Unsaturated Porous Media, edited by M. T. van Genuchten, F. J. Leij, and L. Wu, 
pp. 643-660, Univ. of Calif., Riverside, 1999. pp 643-659

Hund A, Ruta N, Liedgens M (2009) Rooting depth and water use efficiency of tropical maize inbred lines, differing in drought tolerance. Plant Soil 318:311-325. doi: 10.1007/s11104-008-9843-6

Hunter MC, Smith RG, Schipanski ME, et al (2017) Agriculture in 2050: Recalibrating Targets for Sustainable Intensification. Bioscience 67:386391. doi: 10.1093/biosci/bix010

Jarvis NJ (1989) A simple empirical model of root water uptake. J Hydrol 107:57-72

Kirkegaard JA, Lilley JM, Howe GN, Graham JM (2007) Impact of subsoil water use on wheat yield. Aust J Agric Res 58:303-315. doi: 10.1071/AR06285

Kondo M, Murty MVR, Aragones D V. (2000) Characteristics of root growth and water uptake from soil in upland rice and maize under water stress. Soil Sci Plant Nutr 46:721-732. doi: 10.1080/00380768.2000.10409137

Korte CJ, Chu AC. (1983) Some effects of drought on perennial ryegrass swards. Proc new Zeal Grassl Assoc 44:211-216

Kummu M, Guillaume JHA, de Moel H, et al (2016) The world's road to water scarcity: shortage and stress in the 20th century and pathways towards sustainability. Nat Publ Gr 6:1-16. doi: 10.1038/srep38495

Li Y, Huang M (2008) Pasture yield and soil water depletion of continuous growing alfalfa in the Loess Plateau of China. Agric Ecosyst Environ 124:24-32. doi: 10.1016/j.agee.2007.08.007

Lilley JM, Kirkegaard JA (2011) Benefits of increased soil exploration by wheat roots. F Crop Res 122:118-130. doi: 10.1016/j.fcr.2011.03.010

Lilley JM, Kirkegaard JA (2016) Farming system context drives the value of deep wheat roots in semi-arid environments. J Exp Bot 67:3665-3681. doi: $10.1093 / \mathrm{jxb} / \mathrm{erw093}$

Lobet G, Couvreur V, Meunier F, et al (2014) Plant Water Uptake in Drying Soils. Plant Physiol 164:1619-1627. doi: 10.1104/pp.113.233486

Lynch JP (2013) Steep, cheap and deep: An ideotype to optimize water and N acquisition by maize root systems. Ann Bot 112:347-357. doi: $10.1093 / \mathrm{aob} / \mathrm{mcs} 293$

Lynch JP (2018) Rightsizing root phenotypes for drought resistance. J Exp Bot 69:3279-3292. doi: 10.1093/jxb/ery048

Lynch JP, Wojciechowski T (2015) Opportunities and challenges in the subsoil: Pathways to deeper rooted crops. J Exp Bot 66:2199-2210. doi: $10.1093 / \mathrm{jxb} / \mathrm{eru} 508$

Maeght J-L, Rewald B, Pierret A (2013) How to study deep roots-and why it matters. Front Plant Sci 4:299. doi: 10.3389/fpls.2013.00299

Manschadi AM, Christopher J, Devoil P, Hammer GL (2006) The role of root architectural traits in adaptation of wheat to water-limited environments. Funct Plant Biol 33:823-837. doi: 10.1071/FP06055

Marquardt DW (1963) An algorithm for least-sqaures estimation of nonlinear parameters. J Soc Ind Appl Math 11:431-441

Materechera SA, Alston AM, Kirby JM, Dexter AR (1992) Influence of root diameter on the penetration of seminal roots into a compacted subsoil. Plant Soil 144:297-303

Mazzacavallo MG, Kulmatiski A (2015) Modelling Water Uptake Provides a New Perspective on Grass and Tree Coexistence. PLoS One 10:1-16. doi: 10.1371/journal.pone.0144300

McCallum MH, Connor DJ, O'Leary GJ (2001) Water use by lucerne and effect on crops in the Victorian Wimmera. Aust J Agric Res 52:193-201. doi: 10.1071/AR99164

McElrone AJ, Choat B, Gambetta GA, Brodersen CR (2013) From the Soil into the Plant. Nat Educ Knowl 4:5-6

Mclsaac GF, David MB, Mitchell CA (2010) Miscanthus and Switchgrass Production in Central Illinois: Impacts on Hydrology and Inorganic Nitrogen Leaching. J Environ Qual 39:1790-1799. doi: 10.2134/jeq2009.0497

Mitchell RB, Moser LE, Moore KJ, Redfearn DD (1998) Tiller Demographics and Leaf Area Index of Four Perennial Pasture Grasses. Agron J 90:4753. doi: 10.2134/agronj1998.00021962009000010009x 
Nielsen MH, Styczen M, Ernstsen V, et al (2010) Field Study of Preferential Flow Pathways in and between Drain Trenches. Vadose Zo J 9:10731079. doi: 10.2136/vzj2010.0013.

Pietola LM, Smucker AJM (1995) Fine Root Dynamics of Alfalfa after Multiple Cuttings and During a Late Invasion by Weeds. Agron J 87:11611169. doi: 10.2134/agronj1995.00021962008700060021x

Pimentel D, Cerasale D, Stanley RC, et al (2012) Annual vs. perennial grain production. Agric Ecosyst Environ 161:1-9. doi: 10.1016/j.agee.2012.05.025

PrechsI UE, Burri S, Gilgen AK, et al (2015) No shift to a deeper water uptake depth in response to summer drought of two lowland and sub-alpine C3-grasslands in Switzerland. Oecologia 177:97-111. doi: 10.1007/s00442-014-3092-6

Pugliese JY, Culman SW, Sprunger CD (2019) Harvesting forage of the perennial grain crop kernza (Thinopyrum intermedium) increases root biomass and soil nitrogen. Plant Soil 437:241-254

Rasmussen CR, Thorup-Kristensen K, Dresbøll DB (2019) Uptake of subsoil water below 2 m fails to alleviate drought response in deep-rooted Chicory (Cichorium intybus L.). Plant Soil 446:275-290

Rasmussen SB, Blenkinsop S, Burton A, et al (2018) Climate change impacts on agro-climatic indices derived from downscaled weather generator scenarios for eastern Denmark. Eur J Agron 101:222-238. doi: 10.1016/J.EJA.2018.04.004

Richards RA, Passioura JB (1989) A Breeding Program to Reduce the Diameter of the Major Xylem Vessel in the Seminal Roots of Wheat and its Effect on Grain Yield in Rain-fed Environments. Aust J Agric Res 40:943-950

Riday H, Brummer EC (2002) Forage Yield Heterosis in Alfalfa. Crop Sci 42:716-723

Rosegrant MW, Ringler C, Zhu T (2009) Water for Agriculture: Maintaining Food Security under Growing Scarcity. Annu Rev Environ Resour 34:205222. doi: $10.1146 /$ annurev.environ.030308.090351

Sainju UM, Allen BL, Lenssen AW, Ghimire RP (2017) Root biomass, root/shoot ratio, and soil water content under perennial grasses with different nitrogen rates. F Crop Res 210:183-191. doi: 10.1016/j.fcr.2017.05.029

Schoppach R, Wauthelet D, Jeanguenin L, Sadok W (2013) Conservative water use under high evaporative demand associated with smaller root metaxylem and limited trans-membrane water transport in wheat. Funct Plant Biol 41:257-269. doi: 10.1071/FP13211

Sheaffer CC, Tanner CB, Kirkham MB (1988) Alfalfa water relations and irrigation. In: Alfalfa and Alfalfa Improvement-Agronomy Monograph no. 29.

Simunek J, Hopmans JW (2009) Modeling compensated root water and nutrient uptake. Ecol Modell 220:505-521. doi:

10.1016/j.ecolmodel.2008.11.004

Šimůnek J, Šejna M, Saito H, et al (2009) The HYDRUS-1D Software Package for Simulating the One-Dimensional Movement of Water, Heat, and Multiple Solutes in Variably-Saturated Media

Skaggs TH, van Genuchten MT, Shouse PJ, Poss JA (2006) Macroscopic approaches to root water uptake as a function of water and salinity stress. Agric Water Manag 86:140-149. doi: 10.1016/j.agwat.2006.06.005

Smith AG, Han E, Petersen J, et al (2020) RootPainter: Deep Learning Segmentation of Biological Images with Corrective Annotation. BioRxiv 1-16. doi: $10.1101 / 2020.04 .16 .044461$

Sprunger CD, Culman SW, Robertson GP, Snapp SS (2018) How Does Nitrogen and Perenniality Influence Belowground Biomass and Nitrogen Use Efficiency in Small Grain Cereals? Crop Sci 58:1-11. doi: 10.2135/cropsci2018.02.0123

Strock CF, Burridge JD, Niemiec MD, et al (2021) Root metaxylem and architecture phenotypes integrate to regulate water use under drought stress. Plant Cell Environ 44:49-67. doi: 10.1111/pce.13875

Strock CF, Lynch JP (2020) Root secondary growth: An unexplored component of soil resource acquisition. Ann Bot 126:205-218. doi: doi.org/10.1093/aob/mcaa068

Sutanto SJ, Wenninger J, Coenders-Gerrits, AMJ, Uhlenbrook S (2012) Partitioning of evaporation into transpiration, soil evaporation and interception: a comparison between isotope measurements and a HYDRUS-1D model. Hydrol Earth Syst Sci 16:2605-2616. doi: 10.5194/hess-162605-2012 
Svane SF, Dam EB, Carstensen JM, Thorup-Kristensen K (2019) A multispectral camera system for automated minirhizotron image analysis. Plant Soil 441:657-672. doi: 10.1007/s11104-019-04132-8

Svane SF, Svensgaard J, Petersen CT (2020) Meteorological data from the Taastrup Climate and Water Balance Station 2014-2019. In: https://doi.org/10.17894/ucph.8d941a14-b098-4ca5-b177-412f50be1731

Tautges NE, Jungers JM, Dehaan LR, et al (2018) Maintaining grain yields of the perennial cereal intermediate wheatgrass in monoculture v. biculture with alfalfa in the Upper Midwestern USA. J Agric Sci 156:758-773. doi: 10.1017/S0021859618000680

Taylor SA, Asshcroft GL (1972) Physical edaphology. The physics of irrigated and nonirrigated soils

Thorup-Kristensen K, DresbøII DB, Kristensen HL (2012) Crop yield, root growth, and nutrient dynamics in a conventional and three organic cropping systems with different levels of external inputs and $\mathrm{N}$ re-cycling through fertility building crops. Eur J Agron 37:66-82. doi:

10.1016/j.eja.2011.11.004

Thorup-Kristensen K, Halberg N, Nicolaisen M, et al (2020) Digging Deeper for Agricultural Resources, the Value of Deep Rooting. Trends Plant Sci 25:406-417. doi: 10.1016/j.tplants.2019.12.007

Thorup-Kristensen K, Kirkegaard J (2016) Root system-based limits to agricultural productivity and efficiency: the farming systems context. Ann Bot 118:573-592. doi: 10.1093/aob/mcw122

Toreti A, Belward A, Perez-dominguez I, Naumann G (2019) The Exceptional 2018 European Water Seesaw Calls for Action on Adaptation. Earth's Futur 7:652-663

Turral H, Burke J, Faures JM, Faures JM (2011) Climate change, water and food security. Rome Food Agric Organ United Nations 204

Vadez V (2014) Root hydraulics: The forgotten side of roots in drought adaptation. F Crop Res 165:15-24. doi: 10.1016/j.fcr.2014.03.017

Vadez V, Kholova J, Medina S, et al (2014) Transpiration efficiency: new insights into an old story. J Exp Bot 65:6141-6153. doi: $10.1093 / \mathrm{jxb} / \mathrm{eru} 040$

Van Genuchten MT (1980) A closed-form equation for predicting the hydraulic conductivity of unsaturated soils. Soil Sci Soc Am J $44: 892-898$. doi: $10.2136 /$ sssaj1980.03615995004400050002x

Vandoorne B, Beff L, Lutt S, Javaux M (2012) Root Water Uptake Dynamics of Cichorium intybus var. sativum Under Water-Limited Conditions. Vadoze Zo J 11:1-16. doi: 10.2136/vzj2012.0005

Wagoner P (1990) Perennial grain: New use for intermediate wheatgrass. J Soil Water Conserv 45:81-82

Ward PR, Dunin FX, Micin SF (2002) Water use and root growth by annual and perennial pastures and subsequent crops in a phase rotation. Agric Water Manag 53:83-97

Wayman S, Debray V, Parry S, et al (2019) Perspectives on perennial grain crop production among organic and conventional farmers in France and the United States. Agric 9:. doi: 10.3390/agriculture9110244

Wesseling JG (1991) Meerjarige simulaties van grondwateronttrekking voor verschillende bodemprofielen, grondwatertrappen en gewassen met het model SWATRE. SC-DLO Rep 152 DLO Winand Star Ctr, Wa- geningen, Netherlands

White RG, Kirkegaard JA (2010) The distribution and abundance of wheat roots in a dense, structured subsoil - Implications for water uptake. Plant, Cell Environ 33:133-148. doi: 10.1111/j.1365-3040.2009.02059.x

Zheng L, Ma J, Sun X, et al (2018) Estimating the Root Water Uptake of Surface-Irrigated Apples Using Water Stable Isotopes and the Hydrus-1D Model. Water 10:1-12. doi: 10.3390/w10111624

Zwieniecki MA, Thompson M V, Holbrook NM (2003) Understanding the Hydraulics of Porous Pipes: Tradeoffs Between Water Uptake and Root Length Utilization. J Plant Growth Regul 21:315-323. doi: 10.1007/s00344-003-0008-9

\section{Tables}

Table 1 Soil physico-chemical properties at the studied site measured in December 2017. Average values with standard error in brackets. Note: soil texture and chemical properties were analysed by a commercial laboratory (Agrolab, Germany). Texture classification follows the Danish texture 
standard. (TOC) Total Organic Carbon, (N) Nitrogen content, (P) Phosphorus content, (K) Potassium content, (Mg) Magnesium content, (FC) Field Capacity, (PWP) Permanent Wilting Point. $\left(^{1}\right) n=5,\left({ }^{2}\right) n=10$

\begin{tabular}{|c|c|c|c|c|c|c|c|c|c|c|c|c|c|}
\hline $\begin{array}{l}\text { Soil } \\
\text { depth }\end{array}$ & Clay $^{1}$ & Silt $^{1}$ & Sand $^{1}$ & TOC $^{1}$ & $\mathrm{pH}^{1}$ & $N^{1}$ & $\mathrm{P}^{1}$ & $\mathrm{~K}^{1}$ & $\mathrm{Mg}^{1}$ & $\mathrm{FC}^{2}$ & $\mathrm{PWP}^{2}$ & $\begin{array}{l}\text { Soil } \\
\text { bulk }\end{array}$ & Porosity ${ }^{2}$ \\
\hline & $<2 \mu \mathrm{m}$ & $\begin{array}{l}2 \mu \mathrm{m}- \\
200 \mu \mathrm{m}\end{array}$ & $\begin{array}{l}200 \mu \mathrm{m}- \\
2.0 \mathrm{~mm}\end{array}$ & & & & & & & & & Density ${ }^{2}$ & \\
\hline $\mathrm{m}$ & $\%$ & $\%$ & $\%$ & $\%$ & & $\%$ & $\mathrm{mg} / 100 \mathrm{~g}$ & $\mathrm{mg} / 100 \mathrm{~g}$ & $\mathrm{mg} / 100 \mathrm{~g}$ & $\begin{array}{l}\text { Vol } \\
\%\end{array}$ & Vol \% & $\mathrm{g} / \mathrm{cm}^{3}$ & $\%$ \\
\hline $\begin{array}{l}0- \\
0.25\end{array}$ & $\begin{array}{l}14.6 \\
(0.2)\end{array}$ & $\begin{array}{l}16.1 \\
(1.4)\end{array}$ & $\begin{array}{l}67.9 \\
(1.5)\end{array}$ & $\begin{array}{l}0.9 \\
(0.3)\end{array}$ & $\begin{array}{l}7.7 \\
(0.1)\end{array}$ & $\begin{array}{l}0.10 \\
(0.02)\end{array}$ & $\begin{array}{l}4.7 \\
(0.5)\end{array}$ & $\begin{array}{r}11.5 \\
(0.6)\end{array}$ & $\begin{array}{l}7.3 \\
(0.8)\end{array}$ & NA & NA & $\begin{array}{l}1.43 \\
(0.03)\end{array}$ & $\begin{array}{l}45.9 \\
(0.01)\end{array}$ \\
\hline 0.75 & $\begin{array}{l}20.0 \\
(1.1)\end{array}$ & $\begin{array}{l}14.6 \\
(0.8)\end{array}$ & $\begin{array}{l}64.8 \\
(1.7)\end{array}$ & $\begin{array}{l}0.4 \\
(0.1)\end{array}$ & $\begin{array}{l}7.8 \\
(0.1)\end{array}$ & $\begin{array}{l}0.05 \\
(0.01)\end{array}$ & $\begin{array}{l}1.1 \\
(0.2)\end{array}$ & $\begin{array}{l}8.3 \\
(0.5)\end{array}$ & $\begin{array}{l}8.4 \\
(0.9)\end{array}$ & $\begin{array}{l}27.0 \\
(0.5)\end{array}$ & $\begin{array}{l}12.3 \\
(1.3)\end{array}$ & $\begin{array}{l}1.74 \\
(0.003)\end{array}$ & $\begin{array}{l}34.4 \\
(0.001)\end{array}$ \\
\hline 1.5 & $\begin{array}{l}19.5 \\
(0.9)\end{array}$ & $\begin{array}{l}18.2 \\
(0.8)\end{array}$ & $\begin{array}{l}62.1 \\
(1.6)\end{array}$ & $\begin{array}{l}0.1 \\
(0.01)\end{array}$ & $\begin{array}{l}8.0 \\
(0.1)\end{array}$ & $\begin{array}{l}<0.03 \\
(.)\end{array}$ & $\begin{array}{l}0.6 \\
(0.1)\end{array}$ & $\begin{array}{l}6.6 \\
(0.3)\end{array}$ & $\begin{array}{l}7.4 \\
(0.3)\end{array}$ & $\begin{array}{l}30.5 \\
(0.7)\end{array}$ & $\begin{array}{l}10.1 \\
(0.4)\end{array}$ & $\begin{array}{l}1.75 \\
(0.003)\end{array}$ & $\begin{array}{l}33.8 \\
(0.001)\end{array}$ \\
\hline 2.50 & $\begin{array}{l}20.0 \\
(0.6\end{array}$ & $\begin{array}{l}19.3 \\
(0.7)\end{array}$ & $\begin{array}{l}60.7 \\
(0.7)\end{array}$ & $\begin{array}{l}0.1 \\
(0.01)\end{array}$ & $\begin{array}{l}8.0 \\
(0.1)\end{array}$ & $\begin{array}{l}<0.03 \\
(.)\end{array}$ & $\begin{array}{l}0.4 \\
(0.0)\end{array}$ & $\begin{array}{l}6.9 \\
(0.6)\end{array}$ & $\begin{array}{l}8.6 \\
(1.2)\end{array}$ & $\begin{array}{l}27.2 \\
(0.2)\end{array}$ & $\begin{array}{l}12.8 \\
(0.4)\end{array}$ & $\begin{array}{l}1.83 \\
(0.003)\end{array}$ & $\begin{array}{l}30.9 \\
(0.001)\end{array}$ \\
\hline
\end{tabular}

Table 2 Crop factors, compensation factor $\left(\omega_{c}\right)$, feddes parameters, and soil hydraulic parameters for the two layers. Parameters starting with * have been estimated by inverse modelling and standard errors are provided. Number 1 and 2 associated with the soil hydraulic parameters refers to the top and bottom soil layer, respectively. The use of the parameters and the description of the abbreviations are explained in the supplementary material "Hydrus-1D Model functioning and equations". 


\begin{tabular}{|c|c|c|c|c|}
\hline Category & Parameter & Unit & Alfalfa & Intermediate Wheatgrass \\
\hline \multirow[t]{4}{*}{ Crop factor } & Ini & - & 0.4 & 0.7 \\
\hline & Mid & - & 1.2 & 1.15 \\
\hline & End & - & 1.15 & 0.25 \\
\hline & $\omega_{c}$ & - & 0.75 & 0.75 \\
\hline \multirow[t]{5}{*}{ Feddes parameter } & $\mathrm{H} 1$ & $\mathrm{~cm}$ & -10 & 0 \\
\hline & $\mathrm{H} 2$ & $\mathrm{~cm}$ & -25 & -1 \\
\hline & $\mathrm{H} 3_{\text {high }}$ & $\mathrm{cm}$ & -1500 & -500 \\
\hline & $\mathrm{H} 3_{\text {low }}$ & $\mathrm{cm}$ & -1500 & -900 \\
\hline & $\mathrm{H} 4$ & $\mathrm{~cm}$ & -8000 & -16000 \\
\hline \multirow[t]{18}{*}{ Soil hydraulic parameters } & $1-\theta s$ & - & 0.312 & 0.307 \\
\hline & $1-\theta r$ & - & 0 & 0 \\
\hline & $1-a_{m}$ & $\mathrm{~cm}^{-1}$ & 0.0055 & 0.0055 \\
\hline & $1-n_{m}$ & - & 1.19 & 1.19 \\
\hline & ${ }^{*} 1-\mathrm{Ks}$ & $\mathrm{cm}_{\text {day }}{ }^{-1}$ & $12.27 \pm 1.7$ & $0.37 \pm 1.1 e^{-2}$ \\
\hline & *1-L & - & $0.12 \pm 0.1$ & $0.01 \pm 7.7 e^{-4}$ \\
\hline & ${ }^{*} 1-W_{f}$ & - & $0.12 \pm 6.1 e^{-3}$ & $0.11 \pm 2.3 e^{-3}$ \\
\hline & ${ }^{*} 1-a_{f}$ & $\mathrm{~cm}^{-1}$ & $0.12 \pm 1.2 \mathrm{e}^{-2}$ & $0.10 \pm 3.8 e^{-4}$ \\
\hline & ${ }^{*} 1-n_{f}$ & - & $3.90 \pm 0.8$ & $4.92 \pm 0.1$ \\
\hline & $2-\theta s$ & - & 0.289 & 0.320 \\
\hline & $2-\theta r$ & - & 0 & 0 \\
\hline & $2-a_{m}$ & $\mathrm{~cm}-1$ & 0.0013 & 0.0013 \\
\hline & $2-n_{m}$ & - & 1.37 & 1.37 \\
\hline & ${ }^{*} 2-K s$ & $\mathrm{~cm}_{\text {day }}{ }^{-1}$ & $0.90 \pm 6.1 \mathrm{e}^{-2}$ & $1.67 \pm 0.2$ \\
\hline & ${ }^{*} 2-L$ & - & $10.00 \pm 1.2$ & $3.49 \pm 0.6$ \\
\hline & ${ }^{*} 2-W_{f}$ & - & $0.02 \pm 1.5 e^{-3}$ & $0.05 \pm 8.5 e^{-3}$ \\
\hline & ${ }^{*} 2-a_{f}$ & $\mathrm{~cm}^{-1}$ & $0.10 \pm 4.5 e^{-3}$ & $0.10 \pm 1.2 e^{-2}$ \\
\hline & ${ }^{*} 2-n_{f}$ & - & $6.76 \pm 1.1$ & $1.71 \pm 0.2$ \\
\hline
\end{tabular}

Table 3 Comparison of forage biomass, grain yield and thousand kernel dry weight (TKW) of intermediate wheatgrass and harvested biomass of alfalfa in two seasons. Average values with standard error in brackets. Comparisons were made between years, letters that differ indicate significant differences at $(p<0.05)$. *Intermediate wheatgrass straw biomass does not reflect the actual straw yield as measurement errors were introduced by the combine harvester. However, yearly comparisons remain possible assuming that errors were constant across years.

Table 4 Goodness of fit of the different models. Root Mean Square Error (RMSE) 


\begin{tabular}{|c|c|c|c|c|c|c|c|}
\hline & Year & Harvest & \multicolumn{2}{|c|}{$\begin{array}{l}\text { Forage biomass } \\
\text { (ton/ha)* }\end{array}$} & \multicolumn{2}{|c|}{$\begin{array}{l}\text { Grain yield } \\
\text { (ton/ha) }\end{array}$} & TKW \\
\hline \multirow[t]{2}{*}{ Intermediate wheatgrass } & 2018 & - & \multicolumn{2}{|c|}{$4.2(0.4)(a)$} & \multicolumn{2}{|c|}{$0.84(0.1)(a)$} & $7.1(0.05)(a)$ \\
\hline & 2019 & - & \multicolumn{2}{|c|}{$3.8(0.1)(a)$} & \multicolumn{2}{|c|}{$1.04(0.1)(a)$} & $5.9(0.05)(b)$ \\
\hline \multirow[t]{15}{*}{ Alfalfa } & 2018 & \multirow[t]{2}{*}{ June } & \multicolumn{2}{|c|}{$6.9(0.6)(a)$} & \multicolumn{2}{|c|}{-} & - \\
\hline & 2019 & & \multicolumn{2}{|c|}{$8.1(0.4)(b)$} & \multicolumn{2}{|l|}{-} & - \\
\hline & 2018 & \multirow[t]{2}{*}{ August } & \multicolumn{2}{|c|}{$5.8(0.6)(a)$} & \multicolumn{2}{|l|}{-} & - \\
\hline & 2019 & & \multicolumn{2}{|c|}{$5.5(0.3)(a)$} & \multicolumn{2}{|l|}{-} & - \\
\hline & 2018 & October & \multicolumn{2}{|c|}{$2.5(0.1)(a)$} & \multicolumn{2}{|l|}{-} & - \\
\hline & 2019 & & \multicolumn{2}{|c|}{$2.2(0.1)(a)$} & \multicolumn{2}{|l|}{-} & - \\
\hline & & \multicolumn{2}{|c|}{ Compensation level } & Param & & Alfalfa & Intermediate Wheatgrass \\
\hline & & \multirow{2}{*}{$\omega_{c}=0.1$} & & $\mathrm{R}^{2}$ & & 0.71 & 0.79 \\
\hline & & & & RMSE & & 0.01 & 0.01 \\
\hline & & \multicolumn{2}{|l|}{$\omega_{c}=0.75$} & $\mathrm{R}^{2}$ & & 0.69 & 0.85 \\
\hline & & & & RMSE & & 0.01 & 0.01 \\
\hline & & \multicolumn{2}{|l|}{$\omega_{c}=0.875$} & $\mathrm{R}^{2}$ & & 0.65 & 0.82 \\
\hline & & & & RMSE & & 0.01 & 0.01 \\
\hline & & \multirow[t]{2}{*}{$\omega_{c}=0.9$} & & $\mathrm{R}^{2}$ & & 0.62 & 0.80 \\
\hline & & & & RMSE & & 0.01 & 0.01 \\
\hline
\end{tabular}

\section{Figures}




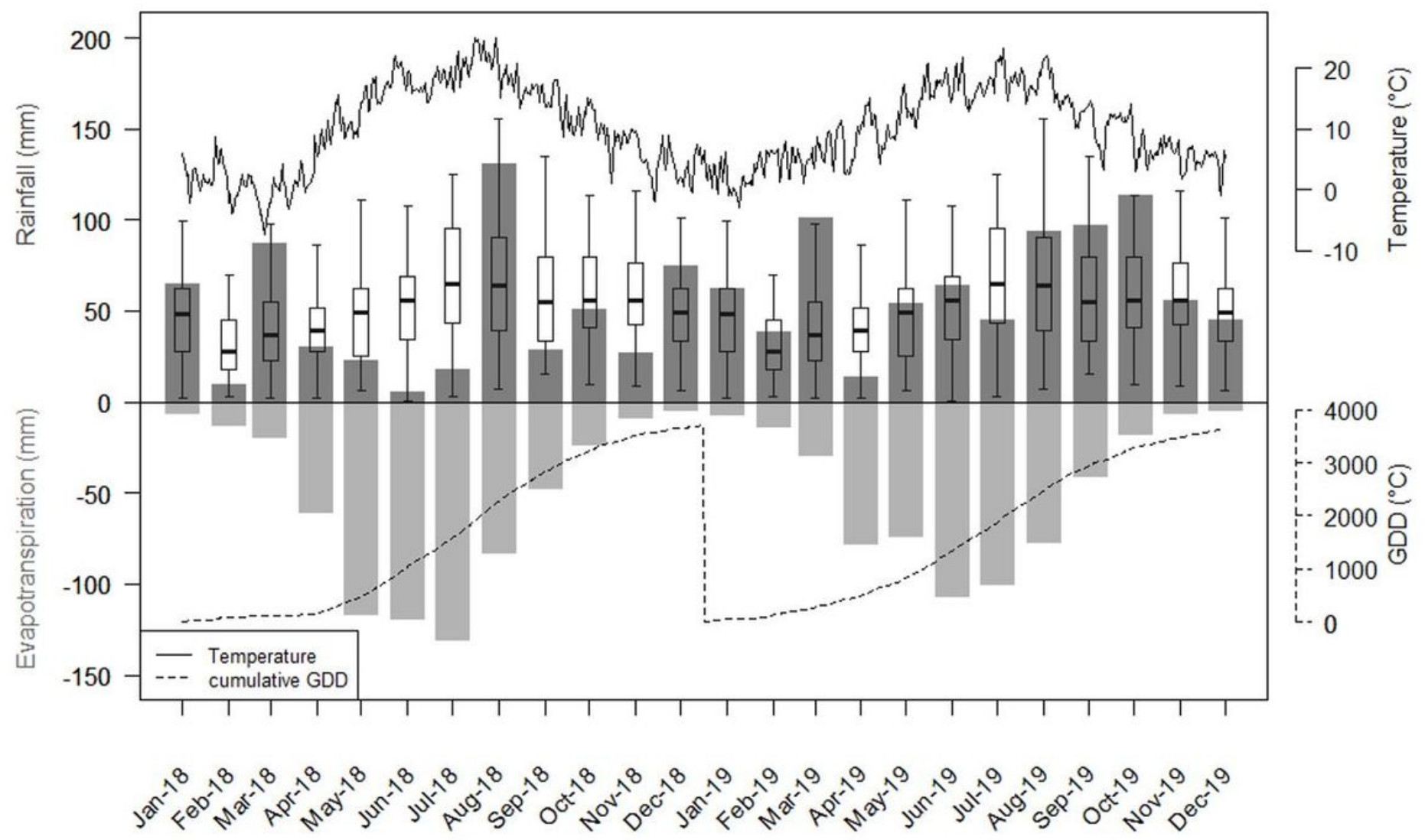

Figure 1

Monthly rainfall (dark grey bars) and reference evapotranspiration (light grey bars). Daily average temperature (solid-line) and cumulative Growing Degree Day (GDD) calculated by the method of (Baskerville and Emin 1969) with base of $0^{\circ} \mathrm{C}$ (dashed-line) at Taastrup, Denmark, from January 2018 to December 2019. Boxplot: Monthly rainfall variability from 1962 to 2008. (Source: (Svane et al. 2020)) 
a) Alfalfa

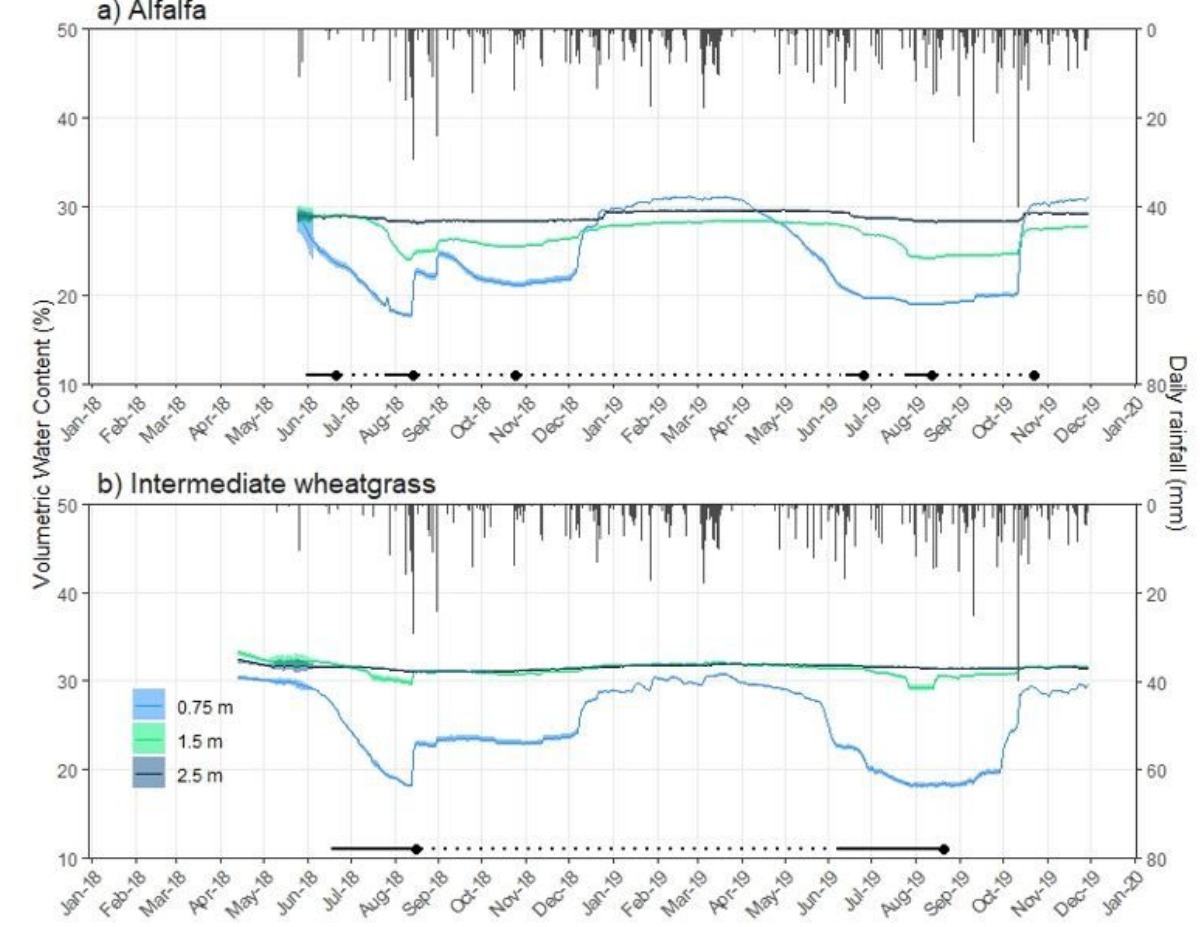

c) Groudwater level

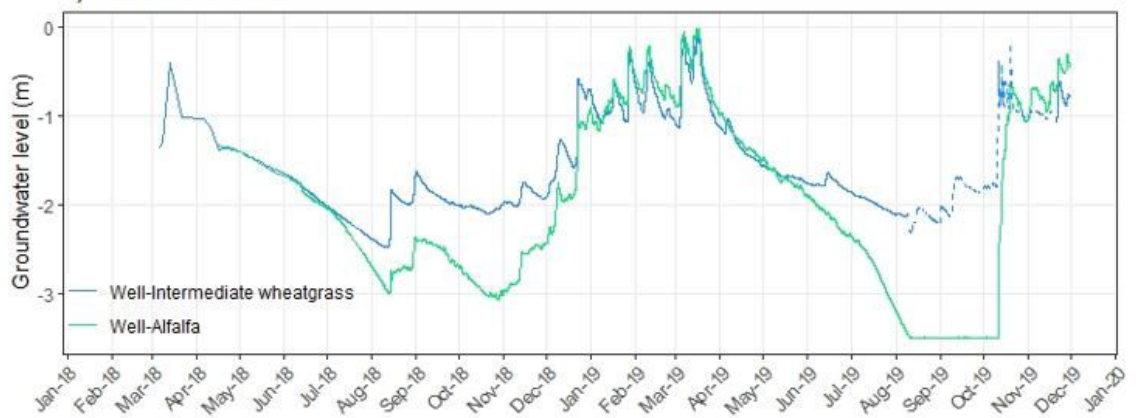

\section{Figure 2}

Soil volumetric water content evolution at $0.75 \mathrm{~m}$ (light blue), $1.5 \mathrm{~m}$ (green) and $2.5 \mathrm{~m}$ (dark blue) soil depth under alfalfa (a) and intermediate wheatgrass (b). Data covers two growing seasons from 01-05-2018 until the 30-11-2019. Daily average value (line) with nalfalfa=6, nintermediate wheatgrass $=9$ per soil depth and corresponding standard error (shade). Grey bars indicate daily rainfall events. ( $\nabla$ ) indicates reproductive stage (i.e. flowering and grain filling), (...) indicates vegetative stage and (๑) indicate harvest time. Groundwater level fluctuation in wells nearby alfalfa (green) and intermediate wheatgrass (light blue) plots $(n=1)$. Note: Dashed line indicates the use of data from a nearby well due to sensor failure (from the 11th of august until the 21 st of November 2019) 


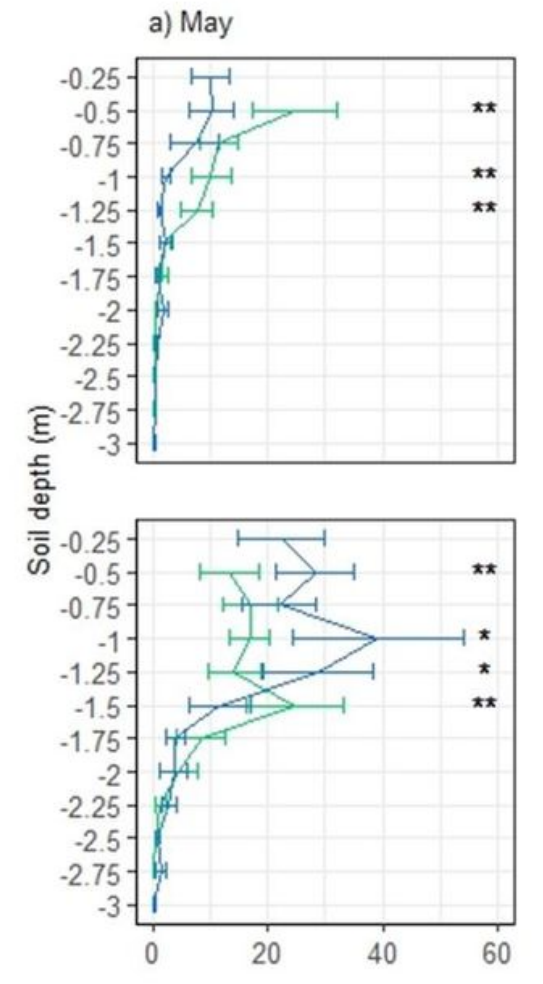

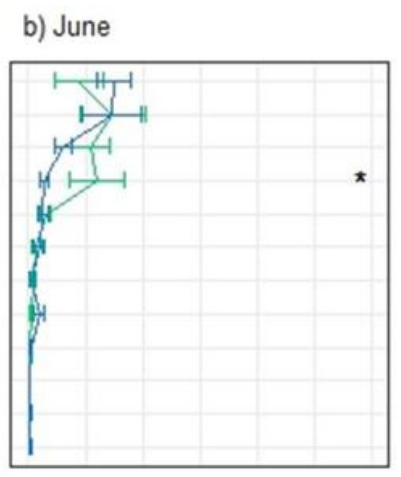

c) July
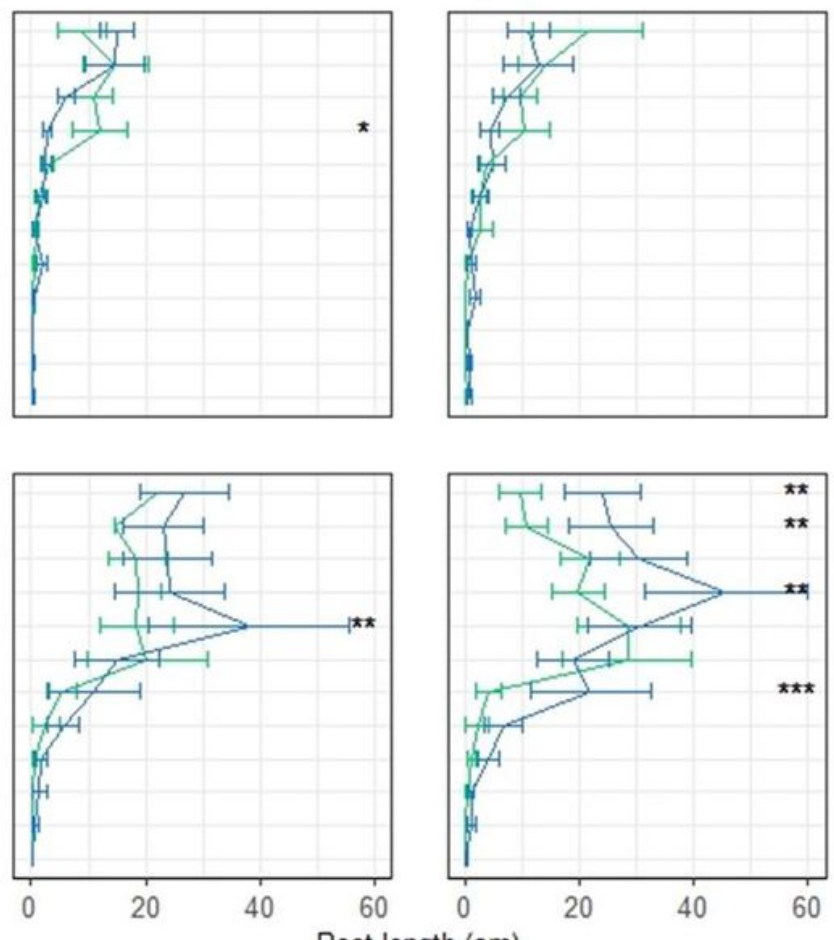

d) August
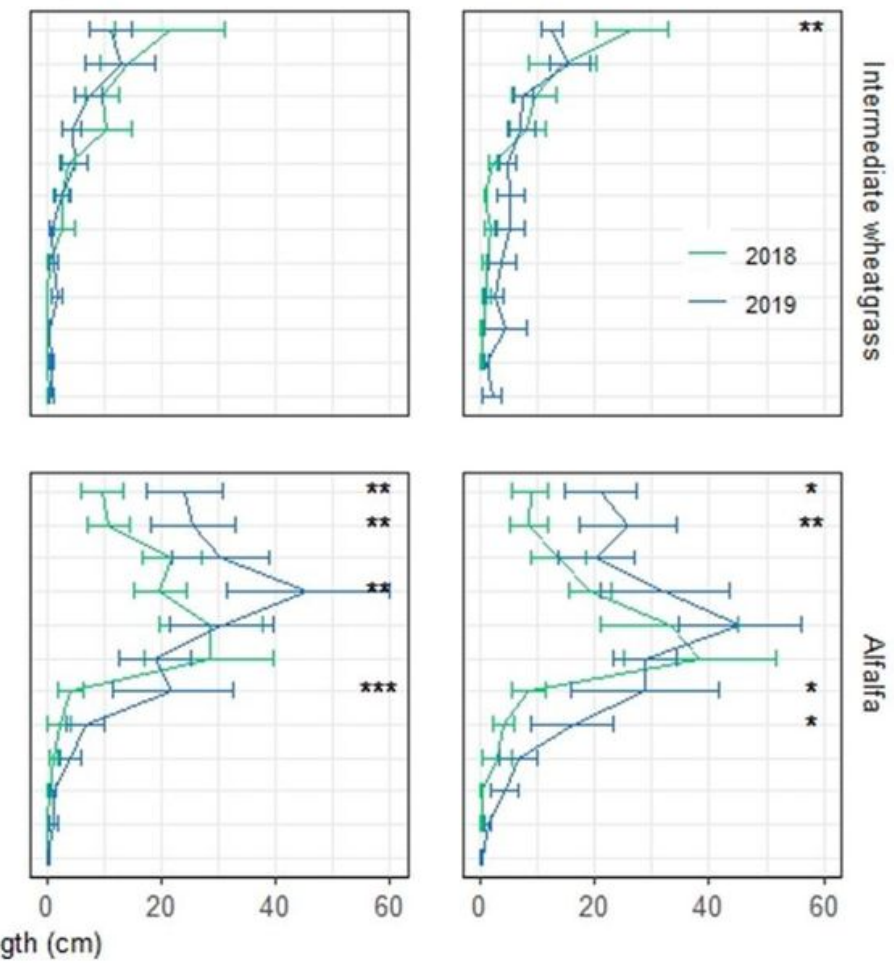

\section{Figure 3}

Monthly root length distribution of intermediate wheatgrass (top row) and alfalfa (bottom row) as a function of soil depth in May (a), June (b), July (c) and August (d) 2018 (green) and 2019 (blue). Average value \pm standard errors (nalfalfa=6, nintermediate wheatgrass = 9). Note: In May 2018, minirhizotron images at $0.25 \mathrm{~m}$ soil depth were not collected due to a technical issue with the camera. Asterisks indicate significance differences, respectively with $* p<0.05, * \star p<0.01$ and ${ }^{* \star *} p<0.001$. Data below $3 \mathrm{~m}$ are not presented due to the absence of roots.

\section{a) Rooting profile (2019)}

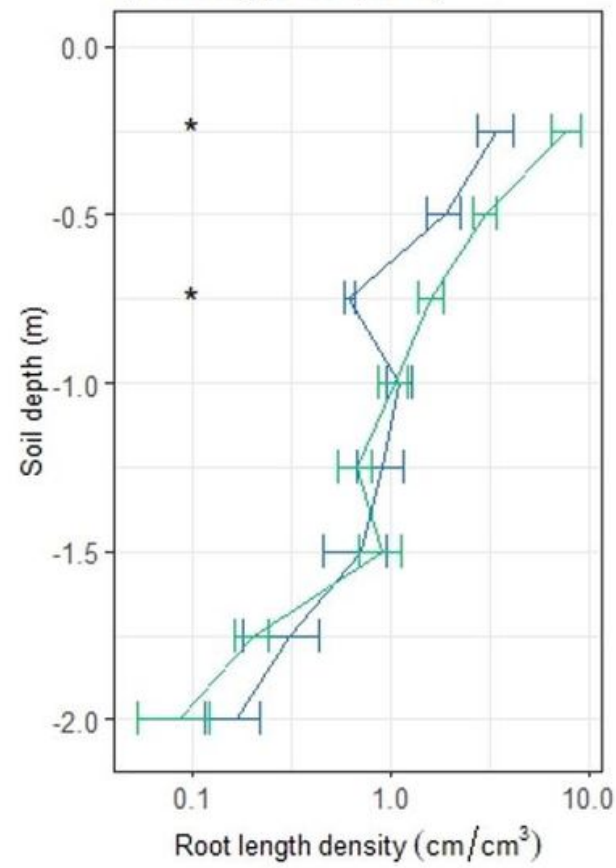

b) Rooting profile (diameter $>1.0 \mathrm{~mm}$ )

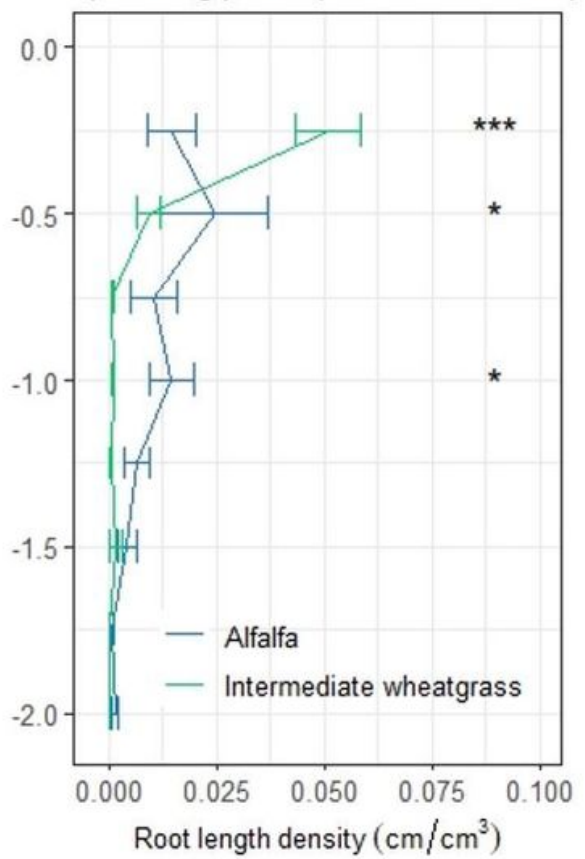

c) Deuterium in soil water (nat. ab.)

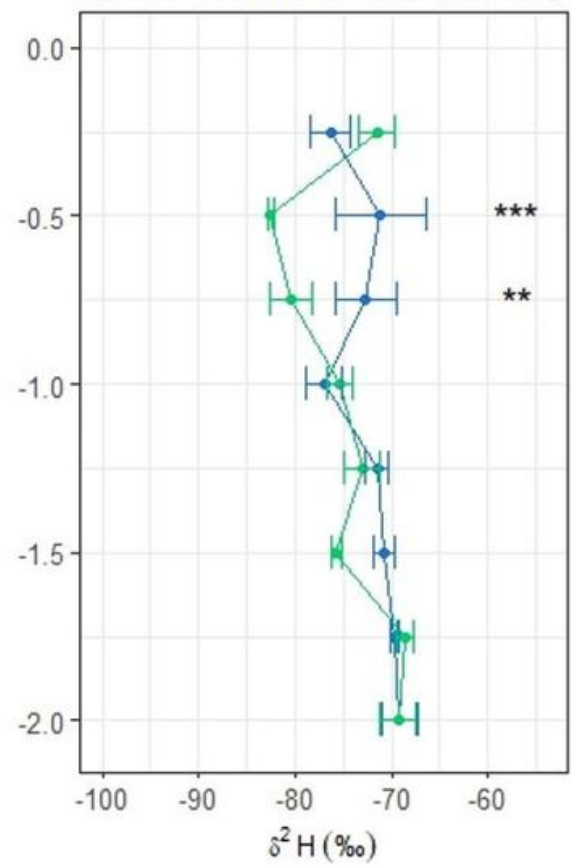

Figure 4 
Root length density (a), root length density of root with a diameter $>1 \mathrm{~mm}$ (b) and soil natural abundance of $\delta 2 \mathrm{H}$ (c) evolution with soil depth of alfalfa (blue) and intermediate wheatgrass (green). Average value \pm standard error. For plot (a) and (b) samples were taken on the 13 June and 18 of July $2019(n=6)$ and for plot (c) samples were taken on 18 of July 2019 only (n=3). Data obtained by coring method. Asterisks indicate significance differences, respectively with * $p<0.05$, ** $p<0.01$ and *** $p<0.001$.

a) Alfalfa

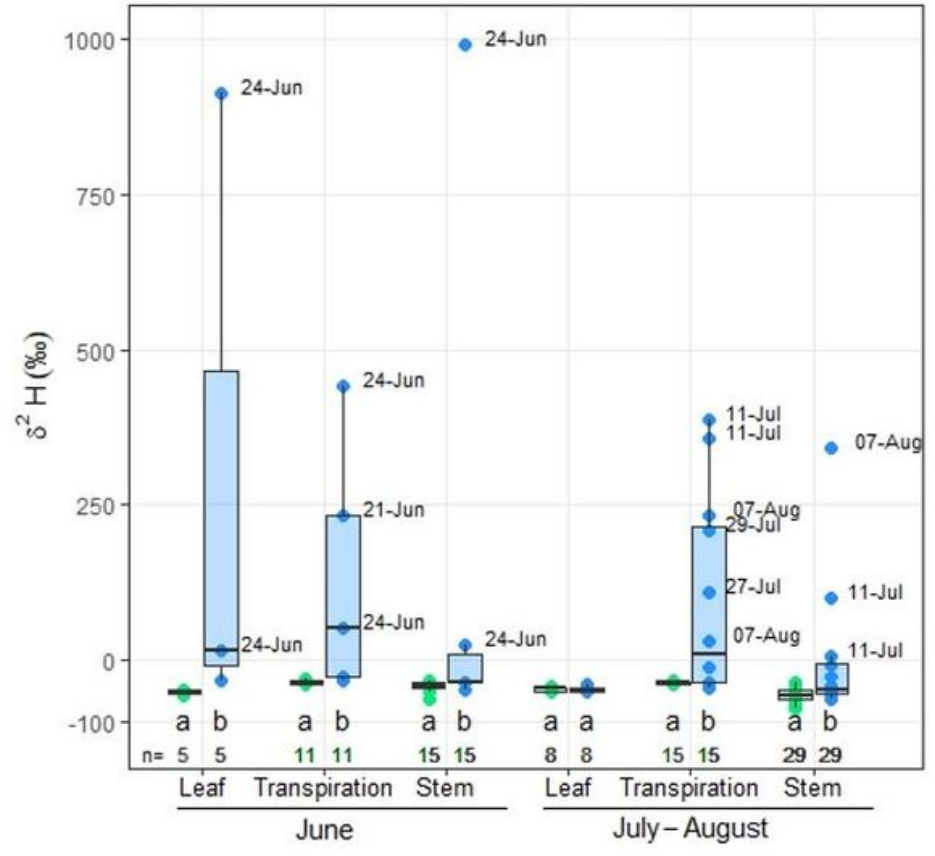

b) Intermediate wheathgrass

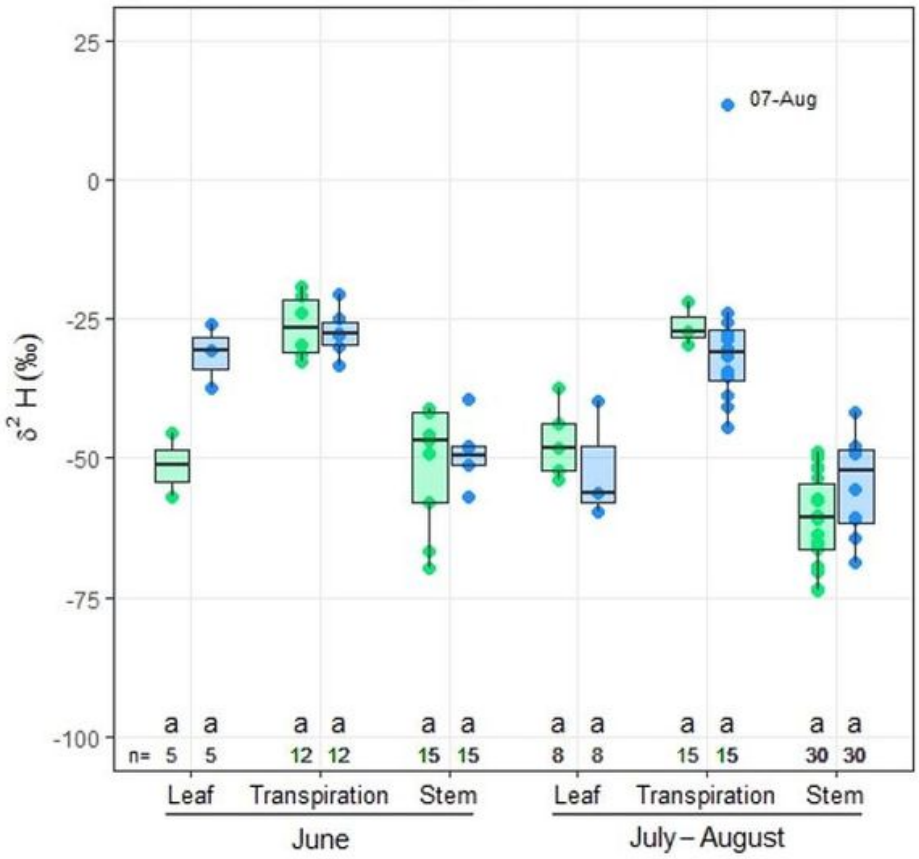

\section{Figure 5}

Boxplots and measured values (points) of $\delta 2 \mathrm{H}$ in water originated from leaf, stem and transpiration of alfalfa (a) and intermediate wheatgrass (b). Sample size is shown in the graph. Comparisons were made between control (green) and enriched sites (blue) for each sample type and time period, letters that differ indicate significant differences at $(\mathrm{p}<0.05)$. Dates of sample collection are provided solely for positive $\delta 2 \mathrm{H}$ values. 


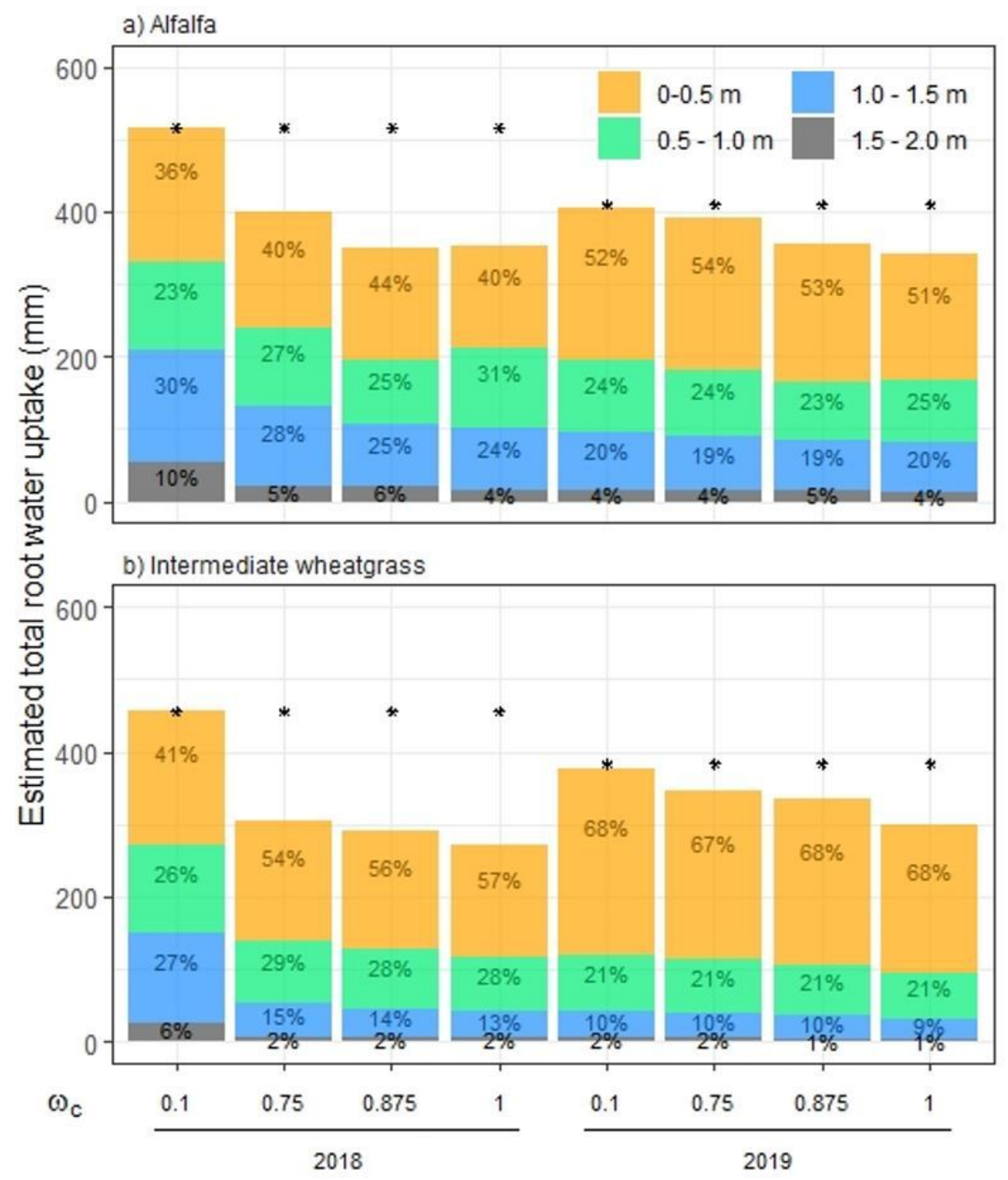

\section{Figure 6}

Comparison of different compensation levels (i.e. $\omega c=0.1,0.75,0.875,1)$ on cumulative root water uptake of alfalfa (a) and intermediate wheatgrass (b) in 2018 and 2019. Actual root water uptake is divided in four root water uptake depths, 0-0.5 m (yellow), 0.5-1.0 m (green), 1.0-1.5 m (light blue) and 1.5-2.0 m (grey). Percentage values indicate the relative contribution of each soil layer. (*) Potential transpiration 


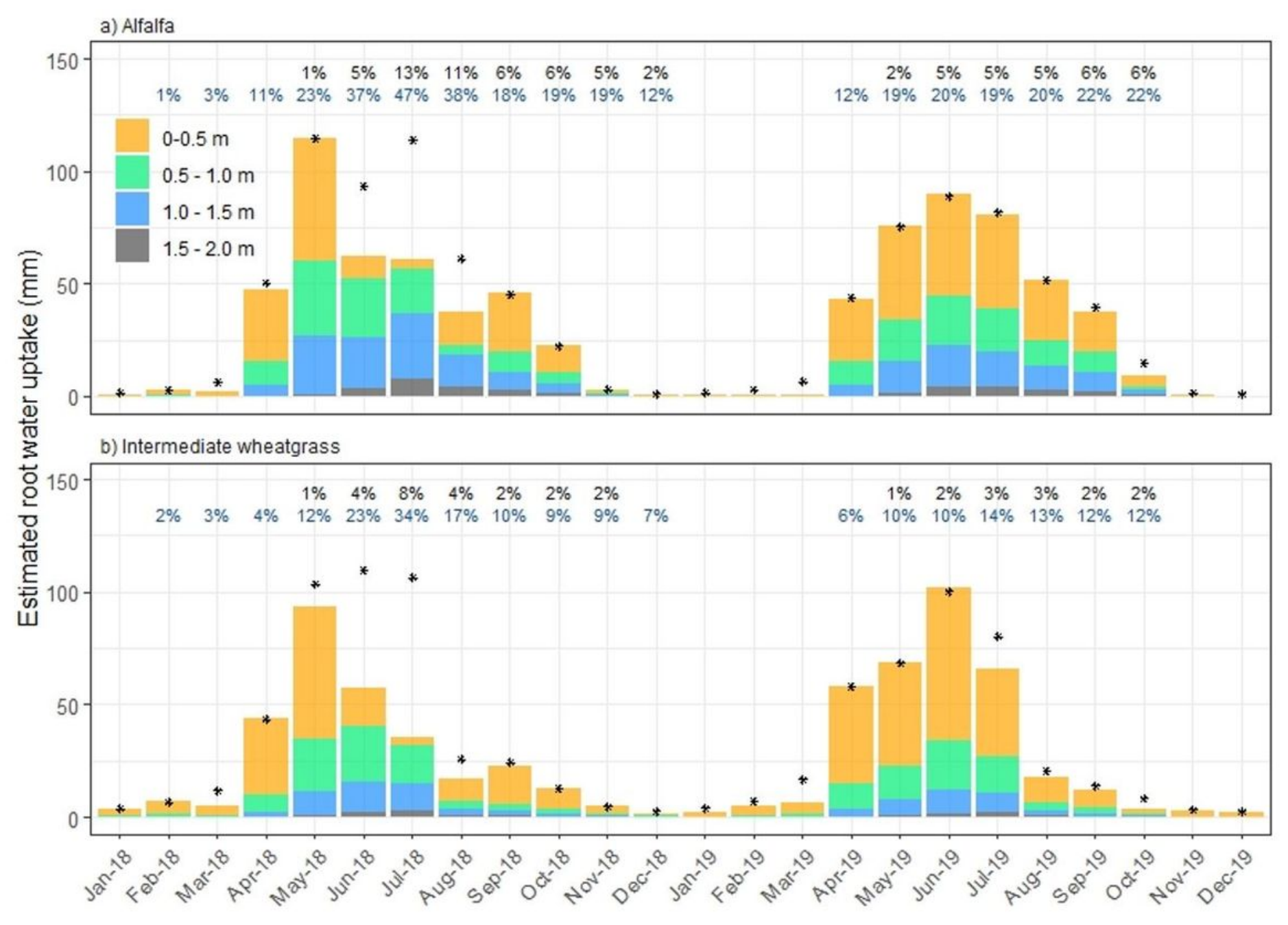

Figure 7

Monthly estimated root water uptake of alfalfa (a) and intermediate wheatgrass (b) over the 2018 and 2019 season. Simulation results for $\omega \mathrm{c}=$ 0.75. Actual root water uptake is divided in four root water uptake depths, 0-0.5 m (yellow), 0.5-1.0 m (green), 1.0-1.5 m (light blue) and 1.5-2.0 m (gray). Percentage values indicate the relative contribution of the 1.0-1.5 m and 1.5-2.0 m soil layer, respectively. (*) Potential transpiration 